جامعـة نيويورك أبـوظـبي 世 NYU |ABU DHABI

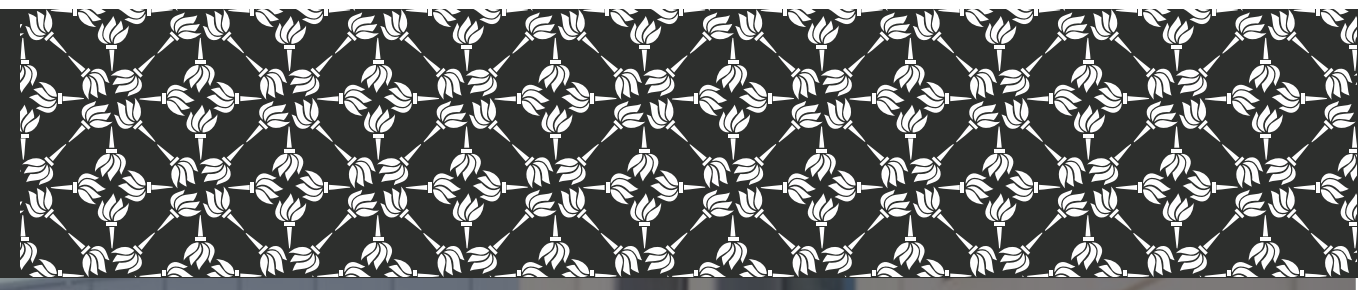

\title{
In the Line of Fire: Political Violence and Decentralization in Colombia
}

\author{
Mario Chacon
}

Working Paper \# 0007

October 2017 


\title{
In the Line of Fire: Political Violence and Decentralization in Colombia*
}

\author{
Mario L. Chacón ${ }^{\dagger}$
}

\begin{abstract}
Policies aimed at increasing the resources and administrative responsibilities of subnational governments are often proposed as a conflict resolution strategy. This paper explores a particular threat to the effectiveness of decentralizing reforms in war-torn countries, namely the capture of local governments by non-state armed actors. These groups are reliant on rents and may increase their violence against local authorities in an attempt to capture local governments in a decentralized system. This relationship between decentralization and conflict is explored using subnational-level data from Colombia during the 1990s, when local fiscal capacity greatly expanded. I exploit a key reform to identify the effect of automatic transfers from the center on conflict casualties. The evidence shows that fiscal transfers are associated with higher murder rates of local authorities and politicians. Moreover, this effect is conditional on the state capacity of localities. These results are robust and consistent with the rent-seeking strategy of paramilitaries and guerrillas during the period.
\end{abstract}

*I would like to thank Alberto Bisin, Elizabeth Dickinson, Abdul Noury, Peter Rosendorff, Andy Schotter, Georgi Derluguian, Nicholas Sambanis, Luis de la Calle, Noam Lupu and other seminar participants at NYUAD, Institut d'Anàlisi Econòmica-CSIC, IMT Lucca, Juan March Institute, and the University of Virginia for their comments and suggestions.

${ }^{\dagger}$ New York University Abu Dhabi, PO Box 129188, Abu Dhabi, UAE. Email: mario.chacon@nyu.edu. 


\section{Introduction}

In recent times, decentralization processes became increasingly common among developing democracies around the world. Latin America for instance, a region characterized historically by its centralized governments, elected more than 70 per cent of all sub-national tier executives during the 1990s (Treisman, 2002). Decentralization has also proven particularly appealing to countries either currently in conflict or with a history of regional strife. Devolving power to local governments, it is argued, can help mitigate grievances by allowing local authorities an extent of autonomy. For example, assuming that newly local governments will offer social services and security, citizens may be less likely to support or join a rebel group helping this way in the "hearts-and-minds" battle between legitimate authorities and insurgents (see, e.g., Berman, Shapiro and Felter 2011) . $!^{1}$ On the basis of this idea, decentralizing reforms have been advocated by development organizations, and many countries including Indonesia, Colombia, and Bolivia have utilized decentralization in part to offer an alternative means of political expression to would-be-rebellious regions.

Are decentralizing reforms that redistribute authority between national and subnational governments convenient for conflict-prone democracies? Although there are many ways in which decentralization may help local authorities win their constituents' loyalty and promote desirable social outcomes, the empowering of local governments can also provide new opportunities for capture, coercion, and increased strife. In particular, the influx of economic resources associated with decentralizing reforms can alter the importance of subnational governments in the overall strategy of insurgencies. This way, non-state armed groups may be incentivized to use their fighting capacity in an attempt to appropriate new local resources in a decentralized system. ${ }^{2}$

This paper contributes to this debate by analyzing this overlooked threat to the effec-

\footnotetext{
${ }^{1}$ Under a similar principle, the improvement of social conditions through development aid has become of one the cornerstones of the US military's counterinsurgency doctrine in recent times (US Army/Marine Corps 2007). This is what some scholars have labeled as the "heart and minds" theory of counterinsurgency (Beath, Christia, and Enikolpov 2012). Although this theory is relevant to the evidence presented in the current paper, development programs aimed at reducing violence and combating insurgencies may or may not involve decentralizing institutions. For instance, Afghanistan's primary aid program, the National Solidarity Program, included the creation of some representative institutions at the village level (see Beath, Christia and Enikolopov 2012, 2013).

${ }^{2}$ Similar mechanisms could be also present during peace and may even trigger a civil war or a secessionist movement. For instance, studies have shown how some forms of political decentralization are indirectly associated with ethnic conflict, secessionism, and terrorism (e.g., Bakke and Wibbels 2006; Brancati 2009).
} 
tiveness of decentralization as a conflict resolution strategy. Namely, I study how decentralization under war influences the incentives of armed actors in a way that is detrimental to the security of local administrations involved in the process. The main idea behind my argument is simple. In a civil war, non-state armed actors are reliant on rents in their fight against the central state or against other armed militia groups. Since decentralization usually involves not only new administrative responsibilities but also new sources of funding for subnational governments, which often lack the "repressive capacity" (Fearon and Laitin 2003) to contain insurgencies, local administrations become an attractive target for non-state armed actors. Thus, decentralization under a state which does not control its territory opens the possibility for non-state armed actors to capture new public resources using selective political violence as an instrument of coercion.

I formalize this idea in a simple rent seeking model in which multiple armed actors compete for a public resource rent. Armed groups invest in violence in the hope of capturing a local government, in which case they will secure the appropriation of the public rent (or at least part of it). In this setting, an exogenous increase in the level of public resources generates a "greed" effect in the sense that actors will make bigger investments in violence trying to capture the newly funded government. I assume some key locality-specific characteristics influence the likelihood of capture. Specifically, high levels of state capacity makes capture less feasible so this will condition the impact of public rents on the likelihood of violence. This implies that while an increase in public rents has a positive impact on the resources invested in violence, this impact decreases as localities have higher levels of state capacity. Hence the model makes two distinct empirical predictions. It predicts a positive effect of public rents on violence and an opposite negative effect of public rents interacted with local state capacity.

I test these predictions using subnational-level data from Colombia during the 1990s, a decade in which a series of decentralizing reforms were implemented in the midst of an escalating conflict between left-wing guerrillas, right-wing paramilitaries, and the central government. My identification strategy uses a constitutional reform in 1993 that increased the size of fiscal resources transferred automatically to the municipalities and modified as well the formula used to distribute these resources. This reform provides a plausible exogenous source of variation in the level of public resources available to municipalities and is ideal to test my predictions for various reasons. First, the reform was designed and 
administered by national agencies so there was little room for manipulation by localities in the allocation of resources. Second, transfers were based on a few socio-demographic characteristics and were not allocated selectively to municipalities based on their levels of violence. Lastly, the entire decentralization process did not include a defense component, so the responsibility for security remained centralized in the hands of the National Police and the National Army. This means that the effect of fiscal decentralization can be isolated from other national-level policies aimed at decreasing conflict.

Using data on selective political murders (i.e., murders of elected officials, candidates, politicians and local leaders) during the 1990s, I find that fiscal transfers from the center are positively related to this form of political violence. Moreover, I show that the impact of transfers and its interaction with various measures of state capacity have the opposite sign and are both statistically significant. For instance, the evidence demonstrates how the presence of local police stations, courts, and notaries, can offset the positive effect of fiscal transfers on violence. This means that the way in which the fiscal reform influenced the conflict between the various armed actors and the local authorities depended critically on the (pre-reform) capacity of local governments. These findings are consistent with the motivating theory and robust to a variety of specifications and tests.

In this way, the relationship between public resources and political violence is interpreted as an increase in the level of coercion and capture of local governments during the post-reform period. This exercise of political influence through violence and intimidation is what some scholars have labeled as "armed clientelism," which is simply "the private appropriation of public goods through violence or the threat of violence" (Eaton 2010, p. 535). In the Colombian context, this form of clientelism is related to a shared incentive non-state armed actors have to control economic resources, shape policies, and consolidate their power locally. Thus, the effect of the decentralizing reforms of the early 1990s on the subsequent levels of political violence is indicative of a perverse dynamic in which local governments became more vulnerable as they became more autonomous and economically viable.

By focusing on one specific reform in one specific country, I am able to identify a specific dimension of decentralization which is relevant for conflict. This is important since fiscal, administrative and political reforms are often implemented simultaneously, making the identification of a particular institutional effect challenging. Another advantage of using 
subnational variation is that I am able to hold constant many unobserved factors which may influence both the level of decentralization and conflict across countries. Lastly, the fiscal resources involved were very substantial (14\% of total central government revenue in 1993) and were part of a national scale reform. Thus this paper complements recent studies estimating the political impact of lower-scale development programs and foreign aid in other conflict environments (e.g., Nielsen et al., 2011; Crost et al., 2013; Nunn and Quian 2013).

Another contribution of this paper is to test and corroborate some of the arguments made by qualitative work on the negative consequences of decentralization in Colombia. For instance, Romero (2000, p.,55) claims that "although the intent of decentralization was to improve democracy, it further polarized the conflict and exposed civilians active in local politics to reprisals from guerrillas, paramilitaries, and security forces." Although these reforms seem to be associated with some positive economic outcomes, in particular with improvements in public education (Faguet and Sanchez 2008), the evidence presented suggests that improvements in social indicators are no guarantee of improvements in security. This is consistent with recent empirical studies looking at the impact of development programs on conflict in other countries fighting insurgencies such as the Philippines (Crost et al., 2013). $!^{3}$

In addition to the works cited above, this paper is related to various literatures. First, several studies have explored the relationship between political decentralization, ethnic conflict, and secessionism. Although there is an ongoing empirical debate in this literature, many of these studies agree on the benefits of some form of decentralization arguing that a deepening of local democracy reduces conflict by bringing citizens closer to their representatives and by giving regional parties the opportunity to influence national-level politics (see e.g., Lijphart 1977; Horowitz, 1985; Diamond and Tsalik 1999). Perhaps closer to my findings are works showing that in some cases decentralization may actually promote conflict (e.g., Leff 1999; Bunce 1999; Snyder 2000; Brancati 2006), or may have a detrimental effect on the quality of democracy and public services (e.g., Fan, Lin and Treisman 2009;

\footnotetext{
${ }^{3}$ Yet, the mechanism suggested by Crost et al., (2013) is different. They find that one of the main development programs in the country lead to an increase in insurgent-initiated violence particularly during the early stages of the program. Hence they conclude insurgencies sabotaged the program anticipating its success could weaken their support in the population.
} 
Machado 2013) In the Colombian case, recent empirical studies (Gallego 2012; Acemoglu et al., 2013), explore how the activity of armed actors has influenced local political competition, turnout, and some national-level policies. None of these works study the relationship between fiscal decentralization and political violence 5

This paper also contributes to a large economics literature focusing on the theoretical and empirical relationship between decentralization and public services (e.g., Besley and Coate 2003; Faguet 2004) and on the political economy of local governance more generally (e.g., Enikolopov and Zhuravskaya 2007). While some of these studies have explored how under decentralization local elites could capture subnational governments more easily, they focus on more "traditional" mechanisms, such as lack of political competition and corruption (e.g., Bardhan and Mookherjee, 2000; Bardhan 2002), assuming a full monopoly of violence by the central state. Thus, the violent capture of democratically elected local governments remains largely unexplored both in the political economy and public economics literature.

The remainder of the paper is organized as follows. Section 2 introduces the theoretical framework and derives the empirical predictions. Section 3 provides a brief introduction to the Colombian context and to the main reforms implemented during the sample period. Section 4 explains the empirical strategy and the data used. Section 5 presents the econometric results and Section 6 some robustness tests. Section 7 discusses some qualitative evidence on the determinants of decentralization in the Colombian case and Section IV concludes.

\section{Theoretical Framework}

In this section, I present a simple model to help interpret the empirical findings. The model is in the spirit of the formal conflict and rent-seeking literature which is based on the canonical "contest model" (e.g., Hirshleifer 1989, Skaperdas 1992 and Nitzan 1994)

\footnotetext{
${ }^{4}$ There is also a political economy literature exploring the potential negative effects of federalism on macroeconomic outcomes (e.g., inflation) and on the quality of fiscal policies of subnational governments (see e.g., Wibbels 2000; Rodden 2002).

${ }^{5}$ Sanchez and Chacón (2006) explores descriptively the determinants of armed conflict in Colombia during the 1974-2002 period and find that transfers are positively correlated with the expansion of some armed groups. The evidence presented in Section 6 shows that this correlation is not robust to the inclusion of municipality and time fixed-effects. The focus on the impact of the 1993 reform on selective political violence during the 1990s is exclusive to this paper.
} 
originated with Tullock (1975). In the model, various armed groups compete for a public rent and factors such as the technology of conflict are crucial in determining the resources invested in the struggle. I make a simple extension to the standard model to allow for the possibility a "draw" in the sense that a local government may resist the violence and keep its resources. The model will highlight how an exogenous change in the value of the public rent influences the incentives to flight and how the strength of local authorities conditions this influence.

Consider $N \geq 2$ non-state armed groups competing for some public rents of value $R^{l}$ in locality $l$. These actors simultaneously invest an amount $e_{j}(j=1,2, . ., N)$ in violence towards local officials in the hope of capturing the public resource. Competition between groups is "imperfectly discriminatory" in the sense that the highest fighting effort may lead to the highest probability of capture but it does not necessarily secure capture. Following Tullock's original formulation, the success of each group is proportional to the ratio of resources invested in violence. Specifically, given a vector of efforts $e=\left(e_{1}, e_{2}, ., e_{N}\right)$, the probability of $j$ 's victory takes the logit form

$$
p_{j}(e)=\left\{\begin{array}{cl}
e_{j}^{m^{l}} /\left(\sum_{i=1}^{N} e_{i}^{m^{l}}\right) & \text { if } \sum_{i=1}^{N} e_{i}^{m^{l}}>0 \\
1 / N & \text { otherwise }
\end{array},\right.
$$

where $m^{l}>0$ represents the effectiveness of violence in determining the winner between groups in $l !^{6}$ To simplify the analysis suppose $m^{l} \leq N /(N-1)$ so there could be some degree of increasing returns in the conflict technology but there is a limit to these.

In addition to the fighting technology, other locality-specific factors could influence the marginal expected returns of fighting expenditures. In particular, the institutional characteristics of each locality could make harder (or easier) for armed actors to influence the political system (e.g., the level of state capacity, the strength of civic society or the presence of local media). These characteristics are modeled in a reduced-form manner by a parameter $\phi^{l} \in[0,1]$ which represents the likelihood that a locality successfully resists the violent capture. This means that even if all groups make positive fighting efforts there is still a chance that none of them will be able to appropriate the public resources of the locality.7 If groups fail to capture the locality they all get zero and lose their fighting

\footnotetext{
${ }^{6}$ The conflict literature has emphasized factors such as skillful rebel leaders, the type of military technology of armed groups and other exogenous characteristics (e.g., rugged terrain), as important determinants of this fighting effectiveness (Blattman and Miguel 2010).

${ }^{7}$ The behavior of local (and national) authorities is therefore non-strategic. Although localities could
} 
expenditures. Assuming that actors are risk neutral, the expected payoff of $j$ is then given by

$$
\mathcal{W}^{j}\left(e_{j}, e_{-j}\right)=\left(1-\phi^{l}\right)\left(\frac{e_{j}^{m^{l}}}{e_{j}^{m^{l}}+\sum_{i \neq j} e_{i}^{m^{l}}}\right) R^{l}-e_{j}
$$

where $e_{-j}=\left(e_{1}, . ., e_{j-1}, e_{j+1}, . ., e_{N}\right)$.

As it is well known, the unique pure-strategy Nash equilibrium of this setting is symmetric and involves all groups investing a positive amount in fighting (see Appendix for all proofs). The equilibrium level of investments depends crucially on the value of the rent, the fighting technology effectiveness and on the feasibility of capture. Higher returns in the conflict technology will lead naturally to higher fighting expenditures. Similarly, an increase in $R^{l}$ will lead to an increase in the level of violence by a simple "greed effect" arising from having a higher prize in the locality; the more public resources the locality has, the more are groups willing to spend to obtain it. This is the first and most basic testable prediction explored in the data.

Furthermore, the strength of the local government conditions the effect of $R^{l}$ and $m^{l}$ on the level of violence. In particular, higher values of $\phi^{l}$ will decrease the magnitude of the greed effect induced by an increase in the public rent. In other words

$$
\frac{\partial e_{j}^{*}}{\partial R^{l}}>0 \text { and } \frac{\partial^{2} e_{j}^{*}}{\partial \phi^{l} \partial R^{l}}<0
$$

where $e_{j}^{*}$ is the equilibrium level of investment for any group $j$.

The intuition for the second comparative static result is straightforward. When the locality is more able to resist the attack of armed groups, the marginal effect of rents on equilibrium investments decreases since each group will have a lower probability of capturing the public rent. Hence, groups will focus their efforts in "weak" municipalities (having low values of $\phi$ ) given an exogenous increase in $R$. The immediate implication is that in municipalities where the government is strong (weak), the amount of fiscal resources available should have a smaller (larger) impact on the levels of political violence. This conditional effect of fiscal rents is the second empirical prediction explored in the data by interacting fiscal transfers to the municipalities with various proxies of local state capacity. ${ }^{8}$

and do indeed allocate their defense expenditures strategically, the particular fiscal reform studied in the paper did not include a defense component and was introduced by the national government unilaterally. For these reasons local governments are not active players in the game.

${ }^{8}$ In this model, peace, defined as having zero fighting investments by all players, is never an equilibrium. 
In summary, this theoretical framework generates two testable predictions. First, as a result of making local governments more valuable, an increase in the amount of fiscal resources transferred by the central government to the municipalities should increase the violence against local officials. The intuition is that fiscal transfers generate a local "greed" effect among the different armed groups active in each municipality. Second, this effect should be lower in municipalities with "stronger" governments which are better equipped to deal with challenges from non-state actors. In such municipalities, the expected return of targeted political violence is lower hence armed actors are less likely to control the public administration and focus instead in capturing the resources of "weaker" municipalities. Therefore, this simple model predicts that the effect of fiscal decentralization on the levels of political violence depends crucially on the capacity and strength of local governments.

\section{Background}

\subsection{Timing of Reforms}

The decentralization process in Colombia started in the mid-1980s and was part of a wave of political and economic liberalization in the region. 9 The devolution of power was gradual and involved mayor political and fiscal reforms. First, a constitutional amendment in 1986 introduced for the first time the popular elections of mayors from 1988 onwards ${ }^{10}$ This process was strengthened in the 1991 Constitution which introduced the direct election of the departmental governors and increased the tax base and rate of fiscal resources transferred directly to the municipalities 11 Specifically, the new constitution stipulated that gradually half of total national revenues had to be transferred automatically to the subnational governments and that the bulk of these transfers had to be spent on edu-

This is because there is a strong incentive to invest a minimal amount when others are not investing (the probability of winning in this case jumps discontinuously from $1 / N$ to 1$)$. If instead of the ratio in efforts $p_{j}$ is a function of the difference in efforts between groups peace could be an equilibrium (see Hirchleifer 1989). In such model, similar comparative static results to the ones discussed will hold in the sense that an increase in $R(\phi)$ would make peace less (more) likely.

${ }^{9}$ Other Latin American countries with a long history of centralized states such as Brazil, Bolivia, and Chile, implemented similar reforms aimed at increasing the autonomy and resources of subnational governments.

${ }^{10}$ Before 1988, mayors were appointed by departmental governors which in turned were appointed directly by the president.

${ }^{11}$ For an detailed account of how the popular election of governors was bargained in the Constitutional Assembly see Falleti (2010; 135-139). 
cation and health services. The main administrative responsibilities of municipalities in the new system were established in 1993 (Law 60) and in 1994 a series of participatory mechanisms (e.g., referenda and popular legislative initiative) were also introduced. Notably, sub-municipal administrative councils (juntas administradoras locales), were made mandatory (Law 136). Hence, the increase in resources and administrative responsibilities of municipalities was preceded by a series of major political reforms. Figure 1 depicts the timeline of some of the main reforms.

\subsection{Law 60 of 1993}

Although the 1991 Constitution gave new responsibilities and resources to the municipalities, the distribution of these resources was not regulated. Thus, new sources of funding for municipalities were created (e.g., the Sistema General de Participaciones (SGP) in Article 356), with the specific goal of improving health, education and social services, but no exact guidelines about how these should be assigned or expended was put in place. This meant that the fiscal transfers to the regions and municipalities continued to follow the rule of Law 12 of 1986 which was based almost entirely on population size 12 The general principle laid out in the Constitution was that the new fiscal system had to address the severe problems of inequality and poverty of the country.

In 1993, Law 60 (known as the Law of Responsibilities and Resources and implemented in 1994) defined a new intergovernmental system of transfers and set the fiscal restrictions of the elected local governments. For example, according to this law, municipalities were supposed to expend the transfers from the central government on the following categories: education (30\%), health (25\%), water and basic sanitation (20\%), free investment (20\%), and sports and culture (5\%). The law also stipulated a gradual increase in the amount transferred directly to the municipalities from 14 per cent of total national fiscal revenues in 1993 to a maximum of 22 per cent in 2001. Figure 2 presents the evolution of fiscal transfers from the center to all the entidades territoriales (i.e., municipal and regional governments) as a percentage of (nominal) GDP for the 19860-2002 period. As seen, topdown transfers increased dramatically during this period. In particular, direct transfers to

\footnotetext{
${ }^{12}$ This law was the first to set restrictions on the discretionality of municipal expenditures, which were founded primarily from the national sales tax. Law 12 also increased gradually the share transferred from $30 \%$ of the total national sales tax revenue to $50 \%$ in 1992.
} 
the municipalities increased from an average of less than 1 per cent in the late 1980s to more than 3 percent of GDP in 2002 13

Law 60 provided not only an important temporal increase in the public resources decentralized but also introduced a key change in the distribution of top-down transfers. Specifically, the law modified the transfer formula and gave, on average, more resources per capita to poor municipalities. For this purpose, both the number of poor people and the overall relative poverty level of the municipality were included as weights in the new formula (these two variables determined approximately $60 \%$ of the "participation" of each municipality in the SPG system until 2001). This was a substantial change since before 1993 central government's transfers were based almost exclusively on population size according to Law 12, 1986. ${ }^{14}$ This change in the system of fiscal transfers is depicted in Figure 3 which shows the evolution of (real) transfers per capita for municipalities below and above the (pre-reform) national 75th poverty percentile. As seen, in the pre-reform period, both the trend and mean size of transfers per capita of relatively rich and relatively poor municipalities are identical. Yet the graph shows how the transfers going to the poorest municipalities increased faster in the post-1993 period. The immediate consequence of this law was then a substantial redistribution of fiscal resources from big, relatively rich, to small, relatively poor, municipalities.

Therefore, an important source of cross-sectional variation in the fiscal resources of the municipalities during the period comes from this specific change in the transferring system used by the national authorities. This is an ideal testing ground for the predictions outlined since this change in the allocation of public resources was exogenous to the local activity of armed groups. Also, there is no apparent relationship between (pre-reform) levels of poverty and the concentration of violence; in fact, in the pre-reform period political violence was on average lower in the relatively poor municipalities (see Section 4). More importantly, the entire process of decentralization did not include a defense component and

\footnotetext{
${ }^{13}$ The rate of automatic transfers to the regional (departmental) governments was also increased by Law 60. These were set to increase from 22.5 per cent of the total national revenue in 1993 to 24.5 per cent in 1996-2001. As a consequence, automatic transfers to lower-level governments reached more than 38 per cent of total national fiscal revenues in 2000 (Baron and Meisel 2003 and DNP).

${ }^{14}$ Article 20, Law 20, stated that $25.8 \%$ of the annual sale tax revenue, one of the main sources of public revenue, had to be distributed to municipalities and to the district of Bogotá D.C. "in proportion to the population of each of these territorial entities" (own translation). By the same law, the percent transferred was set to increase annually to a maximum of $28.5 \%$.
} 
the responsibility for local security remained centralized in the hands of the National Police and the National Army, both of which fall under the authority of the president. Hence, the fiscal rule introduced in 1993 did not allocate resources selectively to municipalities based on their levels of violence or potential security threats.

\subsection{The Rise of Armed Clientelism}

Surprisingly, as the Colombian state became less centralized, local elections were introduced, and local governments received more funding, the conflict erupted (Sanchéz and Chacón 2006; Dube and Vargas 2013). In particular, the first rounds of local elections were accompanied by high levels of violence against local officials and politicians ${ }^{15}$ While this violence may be partly explained by the emergence of left-wing parties, some of which were accused of being political instruments of left-wing insurgent groups, and various paramilitary organizations, the case study literature on the political economy of the conflict suggests that some of the reforms implemented provided a political environment conducive to the increase in violence (e.g., Rangel 1997; Peñate 1999; Restrepo 2003).

The conventional interpretation of how decentralization deteriorated the security of municipalities is that both left-wing guerrillas and right-wing paramilitaries used violence in their attempt to capture new economic and political resources and this way strengthen their control over vast territories of the country. ${ }^{16}$ Fiscal decentralization allowed armed actors to influence directly the expenditure decisions of municipalities, administrative autonomy facilitated the coercion of officials, and the introduction of local elections gave these actors the opportunity to manipulate the electoral process and run their own candidates (Eaton 2010).

This form of political capture at the local level associated with the decentralization is what Colombian scholars have defined as "armed clientelism," which is simply "the private appropriation of public goods though violence or the threat of violence." (Eaton, 2010,

\footnotetext{
${ }^{15}$ For instance, during the first mayoral elections of 1988, there was a wave of political violence against the Comunist-based party Union Patriotica (UP). This party, which was funded by members of the FARC in the early 1980s, won 16 mayoral elections and obtained more than 250 seats in local councils across the country in 1988. During the first rounds of local elections $(1988,1990$ and 1992) it is believe that as many 3,000 UP leaders and supporters were assassinated by paramilitaries and right-wing death squads (Dudley 2003)

${ }^{16}$ Some studies even argue that decentralization promoted the expansion of armed groups into new territories (e.g., Sanchez and Chacón 2006 and Eaton 2010).
} 
535). For example, describing this process Rangel $(2004,245)$ argues that

"Thanks to armed clientelism, paramilitaries influenced the planning and execution of the local budgets. In addition, in many municipalities they are involved in the selection of the local bureaucracies. In this process, armed actors exercise pressure over authorities so that they fill vacancies with their followers and sympathizers. In other cases, the influence takes place in the selection of potential contractors of the locality."

In addition, the case study evidence suggests that the strategy of armed clientelism was particularly common among paramilitary groups. During the decade studied, these rightwing organizations based their military strategy against guerrillas on the capture of newly elected local governments in regions of the country where guerrillas had a strong presence (Romero 2002). In many cases, paramilities used this local control not only to combat guerrillas but also to appropriate the public resources of the towns (Alvaro 2009). The increased influence of paramilitaries in the municipal governments is also consistent with the electoral manipulation and corruption exercised during the late 1990s and early 2000s by the Autodefensas Unidas de Colombia (AUC), an umbrella organization of different paramilitary groups and drug lords formed in 1997. Recent studies show that the AUC had a determinant influence over the political process of some regions and in many cases majors, municipal council members, and even governors had family ties and close links with paramilitary leaders (see e.g., Lopez 2010 and Acemoglu et al., 2013).

Overall, the econometric evidence presented in Section 5, which is based on withinmunicipality variation in the levels of conflict-related violence during the 1990s, is consistent with these arguments and case studies.

\section{Empirical Strategy and Data}

\subsection{Data}

My measure of fiscal resources is per capita transfers from Colombia's central government to the municipal governments. The National Planning Department (DNP) records this information for every fiscal year since 1984. I focus the analysis on the years 1990 through 
2001, and deflate the series using constant pesos of 2000.17 As explained, these funds are earmarked mainly for education, health, water and sanitation services. A small percentage was also denominated as a "free investment" fund which was supposed to finance small development projects proposed by the community and the municipal council (e.g., roads and public facilities). According to a fixed formula, administered by the DNP and based mainly on population and poverty, these amounts are transferred automatically by the Ministry of Finance (Hacienda) to municipalities in several installments during each fiscal year.

The second important source of information quantifies the activity of non-state armed organizations according to national police records and news from the main newspapers in the country. This information is compiled by the Observatory of Human Rights and International Humanitarian Law of the Vice-presidency and contains many categories of events ${ }^{18}$ The analysis focuses on homicidal violence against popularly elected officials, local politicians and public employees which can be unambiguously attributed to non-state actors. The dataset contains two categories, one for murders of elected officials (mayors, council and JAL members, deputies, candidates, and ex-politicians), and a more broad one which includes not only elected officials but also local leaders (e.g., community organizers), and any other non-elected municipal officer (judges, other justice officials, correctional officers, public teachers, among others) ${ }^{19}$ According to the Observatory, between 1988 and 2001, a total of 186 mayors, 651 council and deputies members, 291 politicians, 214 local leaders, and 550 state officials were murdered by armed groups.

To preview the results, Figure 4 shows the evolution of political murders during the sample period spiting municipalities by their pre-decentralization levels of poverty (using the 1985 poverty index). As seen, there is a general downward trend in these murders during the period, a fact which could be partly explained by the very high levels of political violence during the first rounds of local elections at the beginning of the period. ${ }^{20}$ As mentioned, this violence was mostly targeted toward new left-wing parties. Interestingly, political violence

\footnotetext{
${ }^{17}$ There was a major reform to the transfers system in 2001, implemented in 2002, which partially reversed some of the funds received directly by municipalities. Hence I limit the analysis to the pre-2002 period.

${ }^{18}$ http://www.derechoshumanos.gov.co/Observatorio/Paginas/Observatorio.aspx

${ }^{19}$ These categories exclude police and army casualties which are analyzed separately.

${ }^{20}$ Local and regional elections occured in 1988, 1990, 1992, 1994, 1997 and 2000.
} 
was on average lower in the relatively poor municipalities during the pre-1993 period. ${ }^{21}$ More importantly, the gap in political murders between relatively rich and relatively poor municipalities vanished at the end of the post-1993 reform period. As seen, this because the downward trend is steeper for the relatively rich municipalities. I argue this is partly explained by the way this reform distributed fiscal resources across municipalities. In the next section I explore the statistical significance of these differences assuming that in the absence of the reform the pre-reform trends across rich and poor municipalities would have remained constant.

In addition, in various specification tests, I analyze the impact of fiscal resources on acts of selective violence against civilians (e.g., massacres), and acts of indiscriminate violence which include terrorist attacks with small explosive devices, attacks on infrastructure of the municipality (e.g., the electric grid or oil pipelines), and displaced households. To explore a potential effect of transfers on the military strategy and the presence of armed groups across time, I use armed clashes between the military and the guerrillas and military casualties as proxies for changes in presence and territorial expansion.

My theoretical model assumes that multiple armed actors are present in each locality. During the 1990s, the Colombian conflict is better characterized as two-sided battle, with guerrillas on one side and a conjunction of paramilitaries and government forces on the other. Naturally, many municipalities were free from the conflict, especially in regions around the country's main urban centers. To capture this source of heterogeneity in the predicted effect of transfers, I use the armed group presence indicators from the Conflict Analysis Resource Center (CERAC). These yearly (dummy) indicators of guerrilla and paramilitary presence are based on unilateral actions and episodes of combats between these groups. Even though these events are based also on newspaper reports (from 25 different sources), they are produced independently from the events recorded by the Observatory and supplemented by reports from a national network of Catholic priests. Thus this data offers an added check on the soundness of the Observatory data.

To test the prediction that the incentives of non-state armed groups to capture local public rents will depend on the institutional capacity of the municipality, I use mainly indicators based on (physical) state presence. Specifically, I use the number of police

\footnotetext{
${ }^{21}$ This provides further proof that the 1993 reform did not give resource disproportionately to municipalities having already higher levels of political violence.
} 
stations, courts, and notaries in the main urban center (cabecera) of the municipality. These variables are taken from Fundacion Social (1998) and are only available for 1995. ${ }^{22}$ Although all of these institutions are decided at the national level, there could be some type of post-reform trend in local state capacity not captured properly by the model which would make the interaction between transfer and state capacity endogenous. To address this possibility, I use a pre-decentralization measure of local state capacity based on local fiscal capacity. Namely, I use the average share of local tax revenue to total public revenue between 1985 and 1987 (from the DNP). Local taxes are indicative of local state capacity so I expect municipalities having more pre-decentralization sources of local revenue to be more resistant and less vulnerable to the capture of armed groups.

The main control variables used are the exact same factors employed in the transfer rule, namely population (from the National Administrative Department of Statistics, DANE), and poverty rate measured by the NBI index of "unsatisfied basic needs" from the Centro de Estudios sobre Desarrollo Economico (CEDE) at the Universidad de los Andes. In addition, in many models, I include interactions between a full set of time dummies and various timeinvariant characteristics which could condition the "technology of conflict" (i.e., influence $m^{l}$ ) in each municipality. These include altitude, area, precipitation, distance from the departmental capital, and the pre-decentralization level of land inequality, all from the CEDE. Table 1 presents summary statistics for the main variables used in the analysis (see Appendix B for a detailed description of data and sources).

\subsection{Empirical Strategy}

My empirical approach is based on a simple difference-in-differences model where changes in the level of central government's transfers have an impact on violence that depends on some (time-invariant) characteristics of the municipality. Ideally, the analysis would contain a "first stage" to purge the transfer series from any potential source of endogenity. Yet, the exclusion restriction for any of the determinants of the transfer rule during the period (e.g., population, poverty or a post-reform dummy) would not be valid since these could have an independent impact on the conflict. Instead, I follow a control-based approach which

\footnotetext{
${ }^{22} \mathrm{My}$ approach is to interact these time-invariant measures with the yearly level of lagged transfers per capita. This is preferable than using similar contemporaneous time-varying proxies of state capacity since these are most likely endogenous to the conflict and correlated with the main determinants of transfers (e.g., poverty).
} 
controls flexibly for the municipal characteristics determining the transfers and a rich set of differential time trends.

Specifically, I employ a model of the following form:

$$
y_{i t}=\alpha_{i}+\lambda_{t}+\gamma r_{i t-1}+\delta\left(w_{i} \times r_{i t-1}\right)+\mathbf{x}_{i t-1}^{\prime} \boldsymbol{\beta}+\varepsilon_{i t},
$$

where $y_{i t}$ denotes the conflict outcome in municipality $i$ at time $t ; \alpha_{i}$ is a municipality fixed effect and $\lambda_{t}$ is a year effect that captures the national trend. $r_{i t}$ is the $\log$ value of real transfers per capita and $w_{i}$ is a time-invariant measure of state capacity. Hence the coefficients $\gamma$ and $\delta$ capture the main predictions of the theoretical model. $\mathbf{x}_{i t-1}$ is a vector of control variables which includes log population, the poverty index (NBI), a set of interactions between various geographic factors and year dummies, and a full set of departmental fixed effects interacted with year dummies as well. Lastly, $\varepsilon_{i t}$ is an error term capturing all other unobserved factors ${ }^{23}$

To check the robustness of model (3) I also estimate a "long-difference" model of the form:

$$
\triangle y_{i}=d_{j(i)}+\gamma \triangle r_{i}+\delta\left(w_{i} \times \triangle r_{i}\right)+\triangle \mathbf{x}_{i}^{\prime} \boldsymbol{\beta}++v_{i}
$$

In this model, $\triangle y_{i}$ is the change in political violence (or other conflict outcome) in locality $i$, located in department $j$, between the pre-reform period (years 1990-1993) and the postreform period (years 1997-2000), $d_{j(i)}$ is a departmental fixed effect, and similarly

$$
\triangle r_{i}=\log \left(\bar{r}_{i, 97-00}\right)-\log \left(\bar{r}_{i, 90-93}\right)
$$

is the average growth rate of real transfers between these two periods. $w_{i}$ is the same time-invariant measure of state capacity. $\triangle \mathbf{x}_{i}$ represents the average change in a vector of covariates (e.g., poverty rate) and $v_{i}$ an error term representing all omitted factors.

Although this second specification ignores the annual variation in the data is useful to model medium-term trends in the transfers and in the conflict during the sample period. This approach is also possibly more robust since the year-to-year variation in the violence reported could be explained in part by measurement error. Hence, model (4) uses a somewhat different type of variation in the data while keeping a close resemblance to model (3)

\footnotetext{
${ }^{23}$ Because the potential effect of transfers depends on municipal-level characteristics standard errors are clustered at the municipal level.
} 
- in effect, this specification is equivalent to a panel data model with only two periods and a full set of municipality and time effects.

Thus, the key assumption of my empirical approach is that conditioning on all timeinvariant characteristics, the key time-varying variables of the transfer rule, and various time trends, the amount received by the municipality from the center in a given year is uncorrelated to all other time-varying omitted factors that may influence the level of conflict in the locality. While this assumption cannot be attested, is plausible for several reasons. First, transfers are pre-determined by a fixed formula administered by the National Planning Department and beyond control of municipal governments. Second, the main source of temporal and cross-sectional variation in the transfers comes from the 1993 reform which did not give resources selectively to municipalities having more conflict. Lastly, the administrative and fiscal reforms implemented during the sample period did not coincide with similar reforms in other state institutions that could have a direct impact on the conflict (e.g., the National Police or the judicial system).

\section{$5 \quad$ Econometric Results}

Table 2 presents the estimates of a restricted model taking $\delta=0$ and using the aggregate number of political homicides in the municipality as the dependent variable. Thus, the estimates represent the effect of transfers on political violence unconditional of state capacity. Given the theory we expect this effect to be positive (i.e., $\gamma>0$ ). The standard errors reported are robust to arbitrary heteroskedasticity and are clustered at the municipal level (in all panel specifications) and at the department level (in all OLS models).

Column 1 presents a simple bivariate model. In this specification, the coefficient estimate of $\gamma$ suggests that fiscal transfers from the central government have a positive, highly significant, effect on the number of politicians and officers killed in the municipality. The point estimate of this model implies that holding all other factors constant, a one standard deviation increase in the transfer measure increases the number of political murders in the next year by more than 6 percentage points $\left(0.059^{*} 1.08\right)$. Relative to the sample mean this effect represents an increase in political murders of approximately 42 percent. Column 2 includes the transfer formula controls and column 3 adds a rich set of time-invariant 
characteristics interacted with year dummies ${ }^{24}$ As seen, the inclusion of these variables has a negligible effect on the estimate and significance of real per capita transfers.

Columns 4-7 explore the robustness of the panel specification. Columns 4 and 5 present the long-difference estimates of model (4). In addition, to allow for a better description of the underlying count distribution of homicides, I estimate a negative binomial model assuming that killings follow a Poisson distribution (columns 6 and 7). The results of these models are very similar to those in previous columns and are consistent with a positive association between fiscal transfers and targeted political violence. For instance, the marginal effect of transfers when using a negative binomial model with municipality fixed-effects increases to 0.16 (standard error $=0.09$ ) ${ }^{25}$ Overall, the estimates are consistent across the different linear and non-linear specifications.

Table 3 reports the estimates of the full specification (3) which allows the effect of transfers to differ between weak and strong municipalities. Columns 1 and 2 use the number of police stations in 1995 as a proxie for local state strength (these are models without and with controls respectively). In line with the theoretical predictions, both the level of lagged transfers and its interaction with this measure of state capacity have the expected apposite signs. For example, the estimates of column 2 suggest that in a municipality with no local police (approximately $24 \%$ of the municipalities in the sample), an increase in transfers has a positive, highly significant, impact on political killings. This effect is of an order of more than 7 percentage points for a one standard deviation increase in the transfers measure. For the average municipality in the country (having 1.5 police stations), this effect decreases to approximately 4.5 percent and for towns with more than 4.4 stations, the impact of lagged transfers becomes negative. ${ }^{26}$

The remainder of Table 3 presents the results of the same complete specification but using different proxies for state capacity. Columns 3-4 use the number of judicial courts and columns 5-6 use the number of notaries in the urban center. These models yield very

\footnotetext{
${ }^{24}$ In a previous version of the paper I also controlled for a lagged dependent variable in a dynamic model to allow for persistence and mean-reverting dynamics in the level of violence. The results are very similar and available upon request.

${ }^{25}$ These negative binomial models cannot include the same set of differential time trends used in columns 1-3 due to the "incidental parameter" problem. In addition, the fixed-effects negative binomial regression of column 7 identifies the effect of transfers only from municipalities having at least one murder during the sample period.

${ }^{26}$ This negative effect is only valid for very few big municipalities. In the sample, only 59 municipalities (approximately $6 \%$ of the sample) had more than 5 police stations in 1995 .
} 
similar results. For instance, the estimates of column 6 imply that for a municipality with no notaries in its urban center (53\% of the sample), a one standard deviation rise in lagged transfers has a positive impact on political murders of more than 6 percentage points. For municipalities having one notary ( $42 \%$ of the sample), the magnitude of this effect is reduced by almost 50 percent.

Columns 7 and 8 address the potential endogeneity of the interaction between transfers and local state capacity by using a pre-decentralization proxy for state capacity, namely the average local tax revenue as a percentage of total public revenue between 1985 and 1987. Using this measure I get very similar results. For municipalities below the national mean (having on average only 5 percent of their public resources coming from local taxes), the marginal impact of a one standard deviation increase in transfers is approximately 7.3 percentage points. For municipalities above the national mean (so their local taxes represent on average more than $35 \%$ of all their revenue), this effect decreases to 2.8 percent. Furthermore, in municipalities where local taxes represent approximately half of their total revenue, transfers from the center have no effect whatsoever on the levels of political violence. Table 3A (in Appendix) shows the same set of results for the long-difference specification 27

Overall, the panel, long-difference, and non-linear specifications are robust and consistent with the motivating theory. This theory predicts that in a situation of civil war, an exogenous increase in the public resources of subnational governments can have a detrimental impact on local security and that this effect depends crucially on the capacity and strength of these local governments. As shown, both the fiscal transfers to the municipalities and their interaction with various measures of local state capacity have the predicted opposite signs and are statistically significant at conventional levels.

\section{Robustness}

\subsection{Armed Group Presence}

My theoretical model assumes the presence of at least two nonstate armed actors in each locality. In recent times, the Colombian conflict is more complicated since many regions of

\footnotetext{
${ }^{27}$ For the sake of brevity, the non-linear (negative binomial) models are not included in the paper. These results are available upon request.
} 
the country are free from the influence of nonstate armed actors so the central state effectively controls these areas. Many other municipalities are controlled by a single nonstate actor (either a guerrilla or a paramilitary group), and some others are contested between the state and a single nonstate actor (or by two non-state actors). Hence, the presence of different armed factions is an importance source of variation in the effect of transfers on violence. Naturally, the theorized effects are only valid for places where armed groups are present so in municipalities where the state has a monopoly of violence we should observe no relationship between fiscal transfers and political violence.

To explore the validity of the model in this aspect I use the armed group presence indicators of CERAC. As explained, these indicators are constructed from an independent source and complement the homicides data from the Obsevatory. Specifically, I perform a simple sensitivity analysis test in which I split the sample between municipalities having no armed presence (i.e., places where there is no record of presence through the entire sample period), and municipalities having either guerrilla presence, paramilitary presence, or both (i.e., municipalities reporting presence of guerrilla, paramilitaries, or both, in at least one year during the sample period). According to CERAC, during the 1990-2001 period, in 214 municipalities where was no report of armed groups presence while in 342 there was confirmed presence of both paramilitaries and guerrilla groups.

Table 4 presents this sensitivity analysis (for the sake of brevity this analysis is limited to the panel specification). Columns 1-4 reports the estimates of the restricted model including all the controls used previously. As expected, in municipalities where armed actors are not reported to be present, the effect of transfer is not statistically significant different from zero. More importantly, as the number of groups reported to be present in the municipality during the period increase, the estimated effect of transfers per capita increases substantially. For instance, in the sample of municipalities where only guerrillas are reported lagged transfers have a marginal impact of 0.06 (standard error $=0.02$ ) compared to 0.11 (standard error $=0.04)$ in the sample where both guerrilla and paramilitary are reported. In the latter sample, the magnitude of the estimated effect more than doubles compared to the average national effect estimated previously (column 3, Table 2).

Columns 5 through 20 present the results of the full panel model using the different measures for $w_{i}$. Again, the number of armed actors reported is correlated with the estimated magnitude of $\gamma$. These models also confirm that the positive association between 
fiscal transfers and political violence is only valid for municipalities having the presence of at least one nonstate armed actor. In these models, in localities where armed actors are active the effect of transfers and their interaction with local state capacity have the expected signs and are highly significant. Hence, these results provide a "reality check" to the previous estimations and validate one of the main implicit assumptions of the motivating theory.

\subsection{Transfers and Other Conflict Outcomes}

To verify that the effect of transfers from the central government to municipalities on political homicides is not explained by a trend in the conflict not modeled properly (the 1990s was a decade in which many different activities of armed actors exhibit a strong upward trend, see for example Dube and Vargas 2013), Table 5 explores the link between transfers and a variety of other conflict-related outcomes. I divide these outcomes in terrorist attacks, outcomes related to military confrontation between the National Army and the guerrillas, ${ }^{28}$ and acts of violence of nonstate armed actors against civilians (civilian casualties and displaced households).

Columns 1 and 2 show that transfers per capita have no statistically significant effect on the number of explosives activated or on the number of attacks on the infrastructure of the municipality. Similarly, transfers have no impact on the number of military confrontations between the National Army and the guerrillas or on the number of military casualties. This set of results suggests that although fiscal decentralization had an impact on the levels of political violence, it did not had a general "expansion" effect in the conflict in the sense the increase in fiscal resources of some municipalities did not lead to a military expansion of armed groups. Instead, the evidence suggests that in places where armed were already present, the increase in fiscal resources lead to more political violence since local authorities were caught "in the line of fire" of armed actors trying to gain or maintain local control.

Finally, in the last two columns of Table $5 \mathrm{I}$ explore the effect of transfers on two measures of civilian violence: civilian homicides and displaced households. These models show that transfers had a negative, statistically significant, effect on civilian violence during the sample period. Interestingly, these results suggest a possible substitution effect between

\footnotetext{
${ }^{28}$ In the data there is not a single military confrontation between the National Army and paramilitary groups. Similarly, I have no data on military confrontation between guerrillas and paramilitaries.
} 
civilian and selective political violence. This substitution effect could be incorporated in a simple extension of the theory in which armed actors extract both public and private rents. In such extension, as the public rents increase, investments in political violence increase relatively to investments in violence against civilians. Hence, as local administrations receive more resources nonstate armed groups have less "need" to extract resources directly from civilians. This possibility could be consistent with some of the arguments made by papers studying the "hearts and minds" theory of conflict in other settings and is suggested as a future area of research.

\section{Why Decentralize?}

Given the negative impact that the fiscal reform of 1993 had on the subsequent levels of political violence, and the failure of decentralization to stop the conflict more generally, the natural questions are: What were the causes of the decentralization? Why did the elites in control of the national government voluntarily agreed to empower lower levels of government? Were the negative consequences of decentralization unintended?

In this section I briefly present some qualitative evidence addressing these issues. The case study evidence on the historical context of this process generally agrees on the underlying principle of these reforms, which was that local democracy would lead to an increase in efficiency and transparency of public expenditures by strengthening accountability of local representatives (e.g., Alesina, Carrasquilla, and Echevarria 2002).29 Similarly, although the political economy of the fiscal decentralization process implemented in the early 1990s is largely unexplored, some case study works mention the great need to improve the social conditions of poor municipalities, and the incentives to redistribute the fiscal revenues of big cities, as the main factors explaining this reform (see e.g., Angell et al., 2001) ${ }^{30}$

Hence it would appear that the negative consequences of fiscal decentralization on the dynamics of violence were indeed unintended. Interestingly, some of the main political figures at the time who were part of the Constitutional Assembly of 1991 argued that

\footnotetext{
${ }^{29} \mathrm{~A}$ different interpretation of the political decentralization process is given by Escobar-Lemmon (2003) who focuses on the incentives of parties and individual politicians. She finds that Conservatives were more likely to support local elections presumably because they were unlikely to win national elections in the future.

${ }^{30}$ Falleti (2010) argues instead that the timing of these reforms was a crucial determinant explaining the nature of these fiscal reforms.
} 
decentralization was the best way to pacify the country. As Horacio Serpa, leader of the Liberal Party and a prominent member of the Constitutional Assembly, explained:

What did we wanted with that constitution? We wanted to make peace and that constitution is a constitution to make peace. It contains all the political reforms that any revolutionary movement aspires and much more. See? The insurgencies demanded political reforms and with the 1991 Constitution lets say they were left with no platform. (Serpa, Horacio. Interviewed by author, Bucaramanga, January 2013).

On the issue of why the decentralization process did not include a defense component experts argue that the main security threat at the time where the drug cartels from Cali and Medellin, which started fighting a war between themselves and against the national government in their attempt to eliminate the extradition treaty with the US, and not the guerrilla and paramilitary groups. As Antonio Navarro, another prominent member of the Assembly answered when asked about the whether or not the issue of territorial control and political violence was discussed in the Assembly:

I don't recall that well a discussion like the one you ask in the Assembly. The issue of security was focused mainly on how to deal with the issue of drugtracking and on how to recover the possibility of exercising justice. We created the Fiscalia with a semi-accusatory regime and then a special commission in the Legislature, ..., [W]e structured the "no-face" justice system to protect justices from the risk that the mafias represented. (Navarro, Antonio. Personal communication with author, March 2013).

The argument about the preponderance of drug-related violence in the public debate and the relatively minor importance of how guerrillas and paramilitaries could undermine the effectiveness of the decentralizing reforms is expressed by many other political leaders, even from the Conservative party, a collectivity having historically a hard-line stance towards armed actors. As Gustavo Zafra Roldan, a representative of the Conservative party in the Constitutional Assembly argued:

We clearly underestimated the capacity of the paramilitaries. In our defense, paramilitaries were not part of the national debate and the main security issue in 
the country was the violence of the drug cartels. (Zafra, Gustavo. Interviewed by author, Bogota January 2013).

Lastly, on the issue of the timing of the main political reforms, there are two main arguments. The first is based on an increasing popular pressure to democratize the local electoral process. This discontent is consistent with hundreds of civic strikes during the 1980s (Falleti 2010). Second, there seems to be genuine believe that decentralization was only solution to the deep social inequalities of the country and to the increasing threat of the guerrillas (Castro 1988). As Horacio Serpa argued about why they introduced these set of reforms in the new Constitution:

Because we thought peace was going to come. I mean, the constitution was not made for a country at war but for a country in peace. We introduced a series of reforms which were the ones the guerrilla demanded. So we said, with these reforms we will make the peace, the guerrilla will be over, and we will live in peace, as we always wanted. That is the only explanation. (Serpa, Horacio. Interviewed by author, Bucaramanga, January 2013).

\section{Conclusion}

Based on a specific fiscal reform in Colombia during the nineties, this paper revisited the effectiveness of decentralization as a strategy of conflict resolution. In this particular case, political, fiscal and administrative reforms, empowering lower levels of government, were implemented partly to improve the security situation of the country. The implicit assumption was that a decentralized system would better represent the interest of the poor and improve local public goods.

My findings, however, indicate that this logic may be flawed in some conflict situations. Using a series of difference-in-difference models and subnational variation in conflict-related events across Colombian municipalities, I find a positive, statistically significant relationship between (automatic) fiscal transfers from the center and violence against local authorities and politicians. Moreover, I find that this effect is conditional on the state capacity of each locality. In places where the state has very low capacity (e.g., in municipalities having no local police), the impact of transfers on violence is significantly higher. These findings are 
interpreted in the context of a simple rent seeking model in which armed actors use political violence to appropriate the public resources of municipalities. A provocative conclusion is then that decentralization made local governments more vulnerable to the coercion and violence of nonstate armed actors.

My findings suggest that the amount of public resources available for capture is a key determinant of local political violence. This complements recent studies on the economic determinants of other forms of civil war violence (e.g., Dube and Vargas 2013) and validates more generally studies focusing on how local conditions shape the final political outcomes of decentralization (e.g., Bardhan and Mookherjee 2006). Although this paper focuses only on one case, it calls attention to theories placing local political empowerment as a simple, one-dimensional strategy, against insurgencies and terrorist organizations. Finally, the relative importance of public goods provision and local accountability in explaining political violence under civil war is a promising area of further empirical research.

\section{Appendix}

\section{A. Proof of Comparative Statics}

Taking $e_{-j}$ as given, the objective function for any given group $j \in\{1,2, . ., N\}$ is given by

$$
\max _{e_{j} \in \mathbb{R}_{+}}\left\{\left((1-\phi)\left(\frac{e_{j}^{m}}{e_{j}^{m}+\sum_{i \neq j} e_{i}^{m}}\right) R-e_{j}\right)\right\} .
$$

The interior solution to this program is given by

$$
(1-\phi)\left(\frac{m e_{j}^{m-1} \sum_{i=1}^{N} e_{i}^{m}-e_{j}^{m}\left(m e_{j}^{m-1}\right)}{\left(\sum_{i=1}^{N} e_{i}^{m}\right)^{2}}\right) R=1 .
$$

Imposing symmetry and solving for $e_{j}$ we get

$$
e_{j}^{*}=\frac{(1-\phi)(N-1) m}{N^{2}} R \equiv e^{*}
$$

Hence, the equilibrium level of effort for each player is a positive function of $m$ and $R$ and a negative function of $\phi$.

Therefore, we have that

$$
\frac{\partial e^{*}}{\partial R}=\frac{(1-\phi)(N-1) m}{N^{2}}>0
$$




$$
\frac{\partial}{\partial \phi}\left(\frac{\partial e^{*}}{\partial R}\right)=-\frac{(N-1) m}{N^{2}}<0 .
$$

To verify the existence of the interior solution notice how for any $j$

$$
\begin{aligned}
\mathcal{W}^{j}\left(e^{*}\right) & =\frac{(1-\phi)}{N} R-\frac{(N-1)(1-\phi) m}{N^{2}} R \\
& =\frac{(1-\phi)}{N}\left(\frac{N(1-m)+m}{N}\right) R \geq 0
\end{aligned}
$$

for any $m \leq N / N-1$.

\section{B. Data Appendix}

Political homicides: number of mayors, council and JAL members, ex-politicians, candidates, governors, and local leaders murdered between 1990 and 2001. Data from the Programa de Derechos Humanos y Derecho Internacional Humanitario, Presidencia de la República (http://www.derechoshumanos.gov.co) and compiled by the Centro de Estudios sobre Desarrollo Economico (CEDE), Universidad de los Andes.

Central Government Fiscal Transfers: yearly real transfers to municipal governments from 1990 to 2001 from the Departamento Nacional de Planeacion (https://www.dnp.gov.co/). Transfers are deflating using a price index of 2000 from the Banco de la República (Banco Central de Colombia) (http://www.banrep.gov.co/).

Population: Log of total municipal population between 1989 to 2000, from the Departamento Administrativo Nacional de Estadistica (http://www.dane.gov.co).

Poverty: measured yearly by the "unsatisfied basic needs" index, between 1989 to 2000. Data from the Centro de Estudios sobre Desarrollo Economico (CEDE), Universidad de los Andes.

Local State Capacity: physical "institutional presence" measured by the number of police stations, number of courts, number of notaries and by the number of tax collection offices in the "cabecera" municipal, 1995. All from the Fundacion Social (1998). In addition, the average local tax revenue as a percentage of total municipal public income between 1985 and 1987 was used as a measured of pre-dencentralization financial capacity. This data is from the Departamento Nacional de Planeacion.

Conflict Indicators: I use yearly terrorist activity by all non-state armed actors, measured by the number of small explosives and attacks to the infrastructure of the municipality; the intensity of military confrontation measured by the number of armed clashes 
between the National Army and guerrillas (FARC and ELN mostly), and by the number of military casualties; and violence indicators against civilians measured by civilian casualties (related to the armed conflict) and by the number of displaced households from the municipality during 1995 and 2000. All indicators, except for the displaced population, are from the Programa de Derechos Humanos y Derecho Internacional Humanitario and compiled by the CEDE and cover the 1990-2000 period. Displaced households data is from the Survey for Internally Displaced Population by Kirchholff and Ibánez (2001).

Non-State Armed Actors Presence: Yearly dummy indicators of guerrilla presence and paramilitary presence based on conflict events, including armed clashes between groups or unilateral actions between 1990 and 2000. From the Conflict Analysis Resource Center CERAC (http://www.cerac.org.co).

\section{References}

[1] Acemoglu, Daron., James Robinson, and Rafael Santos. 2013. "The Monopoly of Violence: Evidence from Colombia." Journal of the European Economic Association, 11, $\mathrm{S} 1: 5-44$.

[2] Alesina, Alberto., Alberto Carrasquilla, and Juan J. Echevarría. 2002. "Descentralización en Colombia," in Reformas Institucionales en Colombia, FedesarrolloAlfaomega.

[3] Álvaro, Miriam. 2009. "From Weapons to Demobilization, Paramilitary Power in Colombia." Revista Internacional de Sociologia. 67, 1: 59-82.

[4] Angell, Alan., and Pamela Lowden, and Rosemary Thorp. 2001. Decentralizing Development. The Political Economy of Institutional Change in Colombia and Chile. Oxford University Press.

[5] Bakke, Kristin., and Erik Wibbels. 2006. "Diversity, Disparity, and Civil Conflict in Federal States." World Politics, 59, 1:1-50.

[6] Bardhan, Pranab. 2002. "Decentralization of Governance and Development." Journal of Economic Perspectives, 16(4):185-206. 
[7] Bardhan, Pranab., and Dilip Mookherjee. 2000. "Capture and Governance at Local and National Levels." American Economic Review, 90, 2:135-139.

[8] Bardhan, Pranab., and Dilip Mookherjee. 2006. Decentralization and Local Governance in Developing Countries. MIT Press.

[9] Barón, Juan David., and Adolfo Meisel. 2003. "La Desentralizacion y las Disparidades Economicas Regionales en Colombia en la Decada de 1990," CEER, Banco de la Republica, Cartagena.

[10] Beath, Andrew., Fotini Christia and Ruben Enikolopov. 2012. "Winning Hearts and Minds through Development: Evidence from a Field Experiment in Afghanistan," MIT Working Paper.

[11] . 2013. "Empowering Women through Development Aid: Evidence from a Field Experiment in Afghanistan." American Political Science Review, 107, 03: 540557.

[12] Besley, Tim, and Stephen Coate. 2003. "Centralized versus Decentralized Provision of Local Public Goods: A Political Economy Analysis." Journal of Public Economics, 87, 12: 2611-2637.

[13] Bell, Gustavo. 1998. "The Decentralized State: An Administrative or Political Challenge?" In Colombia The Politics of Reforming the State, Eduardo Posada-Carbo (ed). Macmillan Press.

[14] Berman, Eli., Joseph H. Felter and Jacob Shapiro. 2011. "Can Hearts and Minds Be Bought? The Economics of Counterinsurgency in Iraq," Journal of Political Economy, 119, 4:766-819.

[15] Brancati, Dawn. 2006. "Decentralization: Fueling the Fire or Dampening the Flames of Ethnic Conflict and Secessionism?" International Organization, 60, 3:651-685.

[16] Bunce, Valerie.1999. Subversive Institutions: the Design and the Destruction of Socialism and the State. Cambridge University Press. 
[17] Bundel., R and S., Bond. 1998. "Initial Conditions and Moment Restrictions in Dynamic Panel Data Models." Journal of econometrics, 87, 1:115-143.

[18] Crost, Benjamin., Felter Joseph, and Patrick Johnson. 2013. "Aid under Fire: Development Projects and Civil Conflict," unpublished manuscript University of Denver.

[19] Diamond, Larry, and Svetlana Tsalik. 1999. "Size and Democracy. The Case for Decentralization." In Developing Democracy: Toward Consolidation, Larry Diamond(ed). Baltimore: JHU Press.

[20] Dudley, Steven. 2003. Walking Ghosts. Murder and Guerrilla Politics in Colombia. Routledge, New York.

[21] Eaton, Kent. 2010. "The Downside of Decentralization: Armed Clientelism in Colombia." Security Studies, 15, 4: 533-562.

[22] Escobar-Lemmon, Maria. 2003. "Political Support for Decentralization: An Analysis of the the Colombian and Venezuelan Legislatures." American Journal of Political Science, 47, 4:683-697.

[23] Enikolopov, Ruben, and Ekaterina Zhuravskaya. 2007. "Decentralization and political institutions." Journal of public economics, 91,11: 2261-2290.

[24] Faguet, Jean-Paul. 2004. "Does decentralization increase government responsiveness to local needs? Evidence from Bolivia." Journal of public economics, 88, 3:867-893.

[25] Faguet, Jean-Paul., and Fabio Sanchez. 2008. "Decentralization's Effect on Educational Outcomes in Bolivia and Colombia." World Development, 37, 7: 1294-1316.

[26] Falleti, Tulia. 2010. Decentralization and Subnational Politics in Latin America. Cambridge University Press.

[27] Fan, C. Simon, Chen Lin and Daniel Treisman. 2009. "Political Decentralization and Corruption: Evidence from Around the World." Journal of public economics, 93, 1:1434.

[28] Fearon, James., and David Laitin. 2003. "Ethnicity, Insurgency, and Civil War." American Political Science Review, 97: 75-90. 
[29] Fundacion Social. 1998. Municipios y Regiones de Colombia. Una Mirada desde la Sociedad Civil. Antropos.

[30] Gallego, Jorge. 2013. "Civil Conflict and Voting Behavior: Evidence from Colombia." Unpublished paper, New York University.

[31] Hirshleifer, Jack. 1989. "Conflict and Rent-Seeking Success Functions: Ratio vs. Difference Models of Relative Success." Public Choice, 63, 2: 101-12.

[32] Horowitz, Donald. 1985. Ethnic Groups in Conflict. Berkeley, University of California Press.

[33] Kirchhoff, S., and A.M. Ibánez. 2001. "Displacement due to violence in Colombia: determinants and consequences at the household level." ZEF discussion paper no. 41. Bonn University, Bonn.

[34] Laakso, M.; R. Taagepera. 1979. "Effective Number of Parties: A Measure with Application to West Europe." Comparative political studies, 12, 1:3-27.

[35] Leff, Carol S. 1999. "Democratization and Disintegration in Multinational States: The Breakup of the Communist Federations." World Politics, 51, 2:205-235.

[36] Lijphart, Arend. 1977. Democracy in Plural Societies: A Comparative Exploration. New Haven, CT, Yale University Press

[37] Lopez, Claudia. 2010. Y Refundaron la Patria..como Mafiosos y Politicos Reconfiguraron el Estado Colombiano. Bogota: Random House Mondadori.

[38] Machado, Fabiana. 2013. "Decentralization and Accountability: The Curse of Local Underdevelopment." IDB Working Paper No. 397.

[39] Nielse, Richard., Michael Findley, Zachary Davis, Tara Candland, and Daniel Nielson. 2011. "Foreign Aid Shocks as a Cause of Violent Armed Conflict." American Journal of Political Science, 55, 2: 219-232.

[40] Nunn, Nathan., and Nancy Qian. 2013. "U.S. Food Aid and Civil Conflict." American Economic Review, forthcoming. 
[41] Rangel, Alfredo. 1997. "El poder local: objetivo actual de la guerrilla," in Descentralización y Orden Publico, Bogotá: Fescol and Milenio.

[42] Rodden, Jonathan. 2002. "The Dilemma of Fiscal Federalism: Grants and Fiscal Performance around the World." American Journal of Political Science, 46, 3: 670-87.

[43] Romero, Mauricio. 2000. "Changing Identities and Constested Settings: Regional Elites and the Paramilitaries in Colombia." International Journal of Politics, Culture and Society, 4, 1: 51-69.

[44] . 2002. Paramilitaries y autodefensas, 1982-2003. Bogota, Planeta Colombiana.

[45] Sanchez, Fabio., and Mario Chacón. 2006. "Conflicto, Estado y Descentralización: del progreso social a la disputa armada por el control local, 1974-2002," in Nuestra guerra sin nombre. Transformaciones del conflicto en Colombia. Bogotá; Norma.

[46] Skaperdas, Stergios. 1992. "Cooperation, Conflict, and Power in the Absence of Property Rights." American Economic Review, 82, 4: 720-39.

[47] Snyder, Jack. 2000. From Voting to Violence: Democratization and Nationalist Conflict. New York: W W Norton.

[48] Treisman, Daniel. 2002. "Defining and Measuring Decentralization: A Global Perspective," maniscript UCLA.

[49] Tullock, Gordon. 1975. "On The Efficient Organization of Trials." Kyklos 28:745-62.

[50] US Army., Marine Corps. 2007. U.S. Counterinsurgency Field Manual. University of Chicago Press.

[51] Wibbels, Erik. 2000. "Federalism and the Politics of Macroeconomic Policy and Performance." American Journal of Political Science, 44, 4: 687-702. 
Figure 1

Timeline of Reforms

\begin{tabular}{|c|c|c|c|}
\hline $\begin{array}{c}\text { Mayoral } \\
\text { Elections } \\
\text { Introduced } \\
\downarrow\end{array}$ & $\begin{array}{c}\text { Gubernatorial } \\
\text { Elections } \\
\text { Introduced } \\
\downarrow\end{array}$ & $\begin{array}{c}\text { Main fiscal and } \\
\text { administrative } \\
\text { reforms implemented } \\
\downarrow\end{array}$ & $\begin{array}{c}\text { Law } 60 \text { is } \\
\text { modified } \\
\downarrow\end{array}$ \\
\hline \multirow[t]{2}{*}{1988} & 1991 & 1994 & 2001 \\
\hline & $\begin{array}{c}\text { New } \\
\text { Constitution }\end{array}$ & Law 60 & \\
\hline
\end{tabular}


Figure 2

Transfers to Lower Levels of Government and GDP, 1986-2002

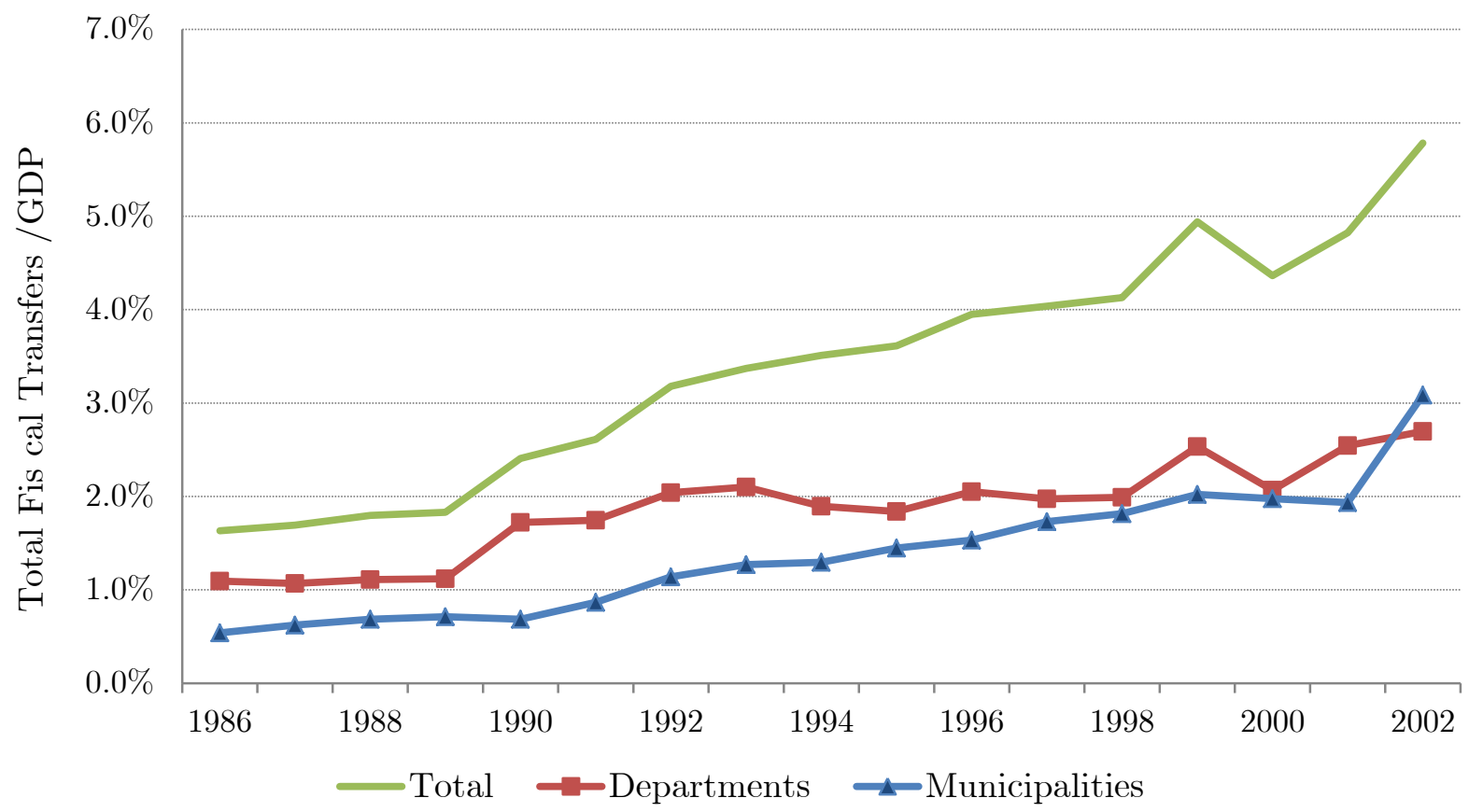

Notes: GDP and transfers data in nominal Colombian pesos. Data from the Direccion de Desarrollo Territorial, Departamento Nacional de Planeacion (DPN), Colombia. Author's calculation.

Figure 3

Real Fiscal Transfers per Capita and Poverty, 1987-2001

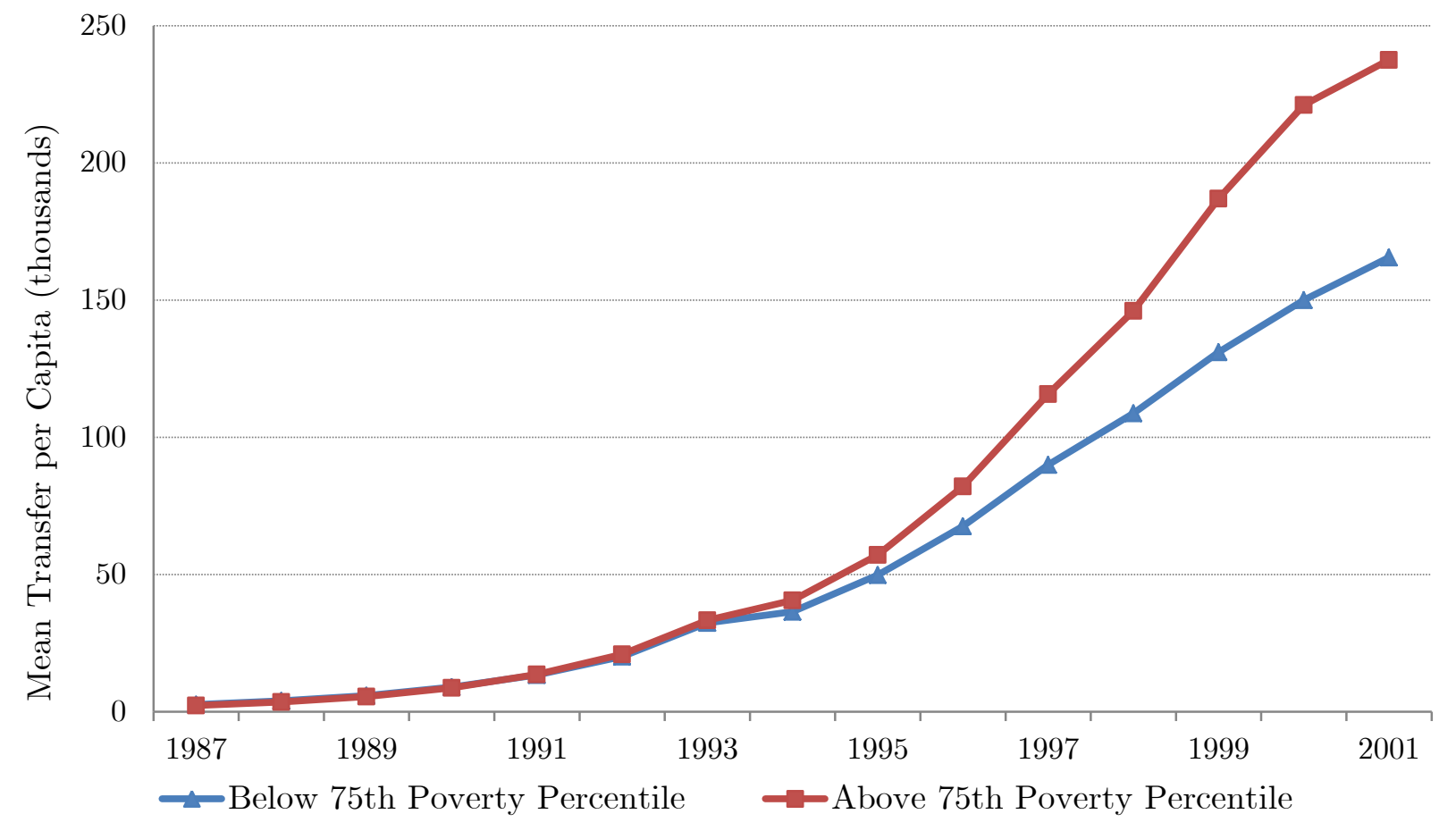

Notes: Fiscal transfers data are from the Departamento Nacional de Planeacion (DPN). Poverty line, measured by the "Unsatisfied Basic Need Index," and population are from the Departmento Nacional de Estadistica (DANE). Author's calculation. The average poverty line in 1987 was $61.3 \%$ and the $75^{\text {th }}$ percentile was $75 \%$. 
Figure 4

A

Homicides Elected Officials and Candidates, 1988-2000

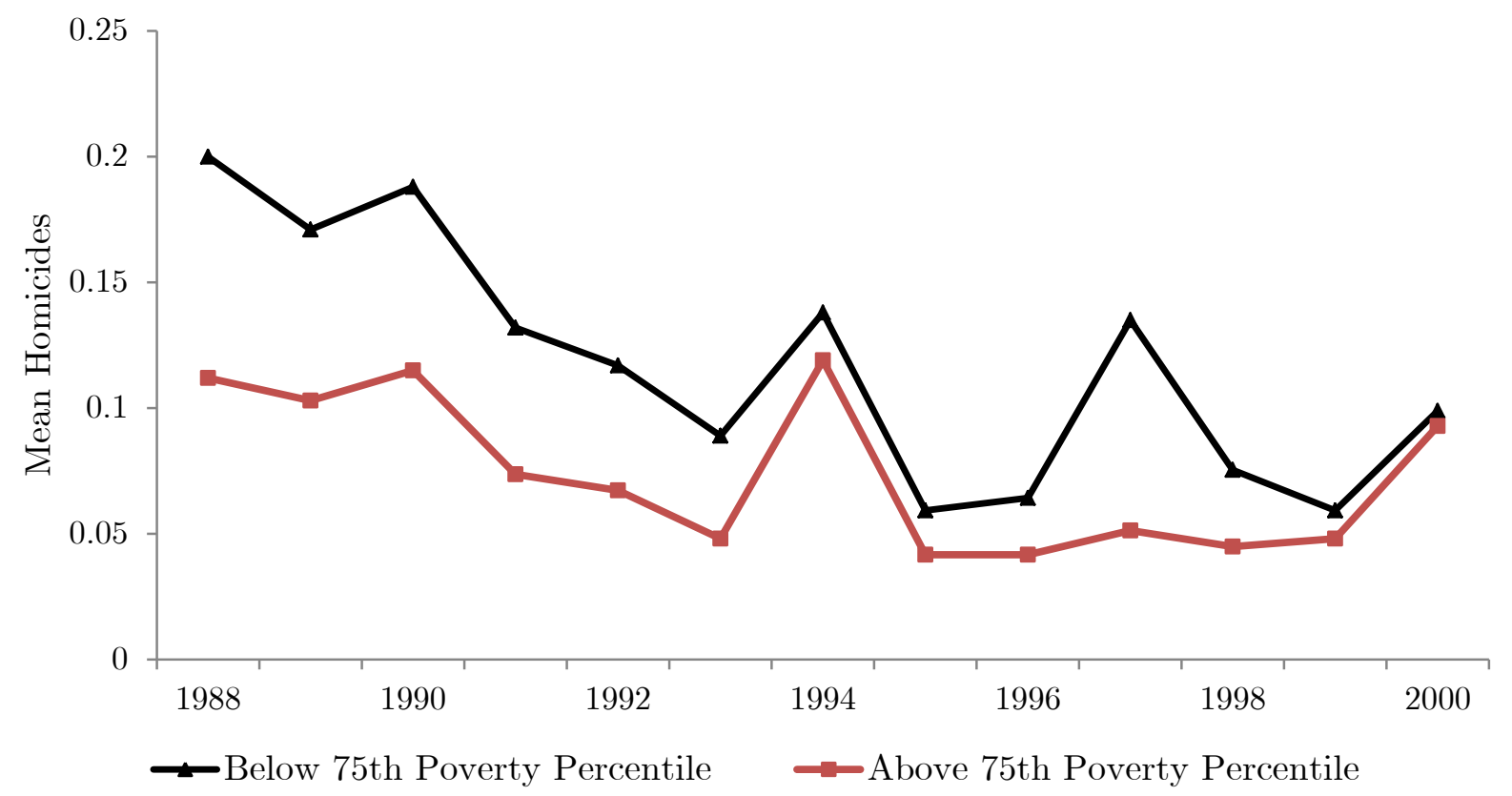

$\mathrm{B}$

Homicides Elected Officials, Candidates, Leaders and other public officers, 1988-2000

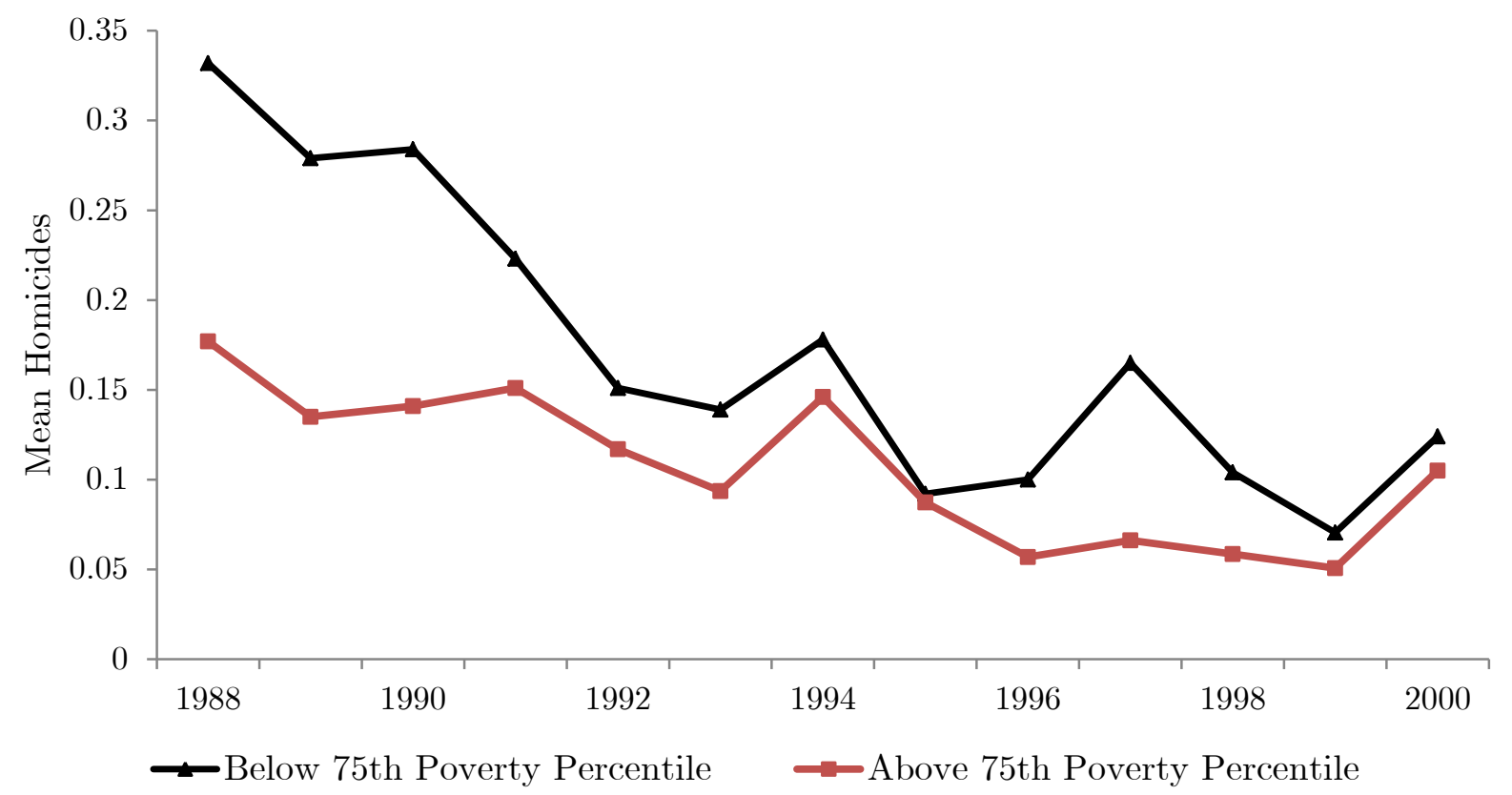

Notes: Graph A: Homicides of elected officials, politicians and candidates, Graph B homicides of all public employees (elected and non-elected) and other politicians. Data from the Observatorio de DDHH y DIH, Vicepresidencia de la Nacion Poverty percentiles based on the NBI index of 1985 from the DANE. Author's calculations 
Table 1-Descriptive Statistics

\begin{tabular}{|c|c|c|c|c|c|c|}
\hline \multirow[t]{2}{*}{ Sample Period: 1990-2000 } & Mean & Std. Dev. & Min. & Max. & Obs. & Mun. \\
\hline & (1) & $(2)$ & (3) & (4) & $(5)$ & $(6)$ \\
\hline \multicolumn{7}{|l|}{ A. Political Homicides } \\
\hline Elected Officials & 0.10 & 0.43 & 0 & 12 & 11,264 & 1,024 \\
\hline $\begin{array}{l}\text { All public employees } \\
\text { (elected }+ \text { non-elected officials) }\end{array}$ & 0.14 & 0.61 & 0 & 17 & 11,257 & 1,024 \\
\hline \multicolumn{7}{|l|}{ B. Central Gov. Trasfers } \\
\hline Log (per-capita transfer) & 3.81 & 1.08 & -6.64 & 7.19 & 11,255 & 1,024 \\
\hline$\Delta \log (\mathrm{pc}$ transfers $)$ & 1.98 & 0.49 & -1.57 & 3.95 & 1,024 & 1,024 \\
\hline \multicolumn{7}{|l|}{ C. Other Conflict Outcomes } \\
\hline Terrorists attacks (explosives) & 0.39 & 2.35 & 0 & 71 & 11,257 & 1,011 \\
\hline Attacks against infrastructure & 0.28 & 2.40 & 0 & 105 & 11,257 & 1,012 \\
\hline Army combats with guerrillas & 0.49 & 1.51 & 0 & 33 & 11,257 & 1,013 \\
\hline Military casualties & 0.21 & 2.26 & 0 & 177 & 11,257 & 1,014 \\
\hline \multicolumn{7}{|l|}{ D. Violence against Civilians } \\
\hline Homicides & 0.91 & 4.12 & 0 & 194 & 11,257 & 1,011 \\
\hline Displaced households (1995-2000) & 9.69 & 82.22 & 0 & 3,741 & 4,806 & 792 \\
\hline \multicolumn{7}{|l|}{ E. Controls } \\
\hline Log (population) & 9.55 & 1.04 & 6.50 & 15.66 & 11,257 & 1,024 \\
\hline Poverty rate (NBI) & 49.95 & 20.00 & 5.50 & 107.80 & 11,264 & 1,024 \\
\hline Urban Rate & 0.38 & 0.23 & 0.02 & 1.00 & 11,257 & 1,024 \\
\hline \multicolumn{7}{|l|}{ F. State Capacity } \\
\hline Police Stations (1995) & 1.54 & 7.59 & 0 & 209 & 989 & 989 \\
\hline Courts (1995) & 3.42 & 17.15 & 0 & 469 & 995 & 995 \\
\hline Notaries (1995) & 0.72 & 3.56 & 0 & 98 & 988 & 988 \\
\hline Local Tax Revenue (1985-1987) & 0.19 & 0.15 & 0 & 0.88 & 997 & 997 \\
\hline \multicolumn{7}{|l|}{ G. Geographic Controls } \\
\hline Altitude (mt) & $1,158.38$ & 897.73 & 2 & 3,087 & 1,061 & 1,061 \\
\hline Size (sq km) & $1,003.01$ & $2,809.62$ & 15 & 42,178 & 1,061 & 1,061 \\
\hline Distance to dpt. Capital (km) & 120.15 & 97.40 & 0 & 600 & 1,061 & 1,061 \\
\hline
\end{tabular}

Note: see main text and Appendix B for variable definitions and sources. 
Table 2

The Effect of Fiscal Transfers on Political Violence, Restricted Model

\begin{tabular}{|c|c|c|c|c|c|c|c|}
\hline \multirow[t]{2}{*}{ Dependent variable: } & \multicolumn{7}{|c|}{ Homicides of Public Officials, Politicians and Candidates } \\
\hline & $\begin{array}{c}\mathrm{FE} \\
\mathrm{OLS} \\
(1) \\
\end{array}$ & $\begin{array}{c}\mathrm{FE} \\
\mathrm{OLS} \\
(2) \\
\end{array}$ & $\begin{array}{c}\mathrm{FE} \\
\mathrm{OLS} \\
(3) \\
\end{array}$ & $\begin{array}{c}\text { Long- } \\
\text { Difference } \\
(4) \\
\end{array}$ & $\begin{array}{c}\text { Long- } \\
\text { Difference } \\
(5) \\
\end{array}$ & $\begin{array}{c}\text { Negative } \\
\text { Binomial } \\
(6)\end{array}$ & $\begin{array}{c}\text { FE Negative } \\
\text { Binomial } \\
(7)\end{array}$ \\
\hline Log (per-capita CG transfer) $)_{t-1}$ & $\begin{array}{c}0.059^{* * *} \\
(0.014)\end{array}$ & $\begin{array}{c}0.046^{* * *} \\
(0.013)\end{array}$ & $\begin{array}{c}0.054^{* * *} \\
(0.017)\end{array}$ & $\begin{array}{c}0.079^{* * *} \\
(0.027)\end{array}$ & $\begin{array}{c}0.065^{* *} \\
(0.027)\end{array}$ & $\begin{array}{c}0.033^{* * *} \\
(0.008)\end{array}$ & $\begin{array}{l}0.163^{*} \\
(0.094)\end{array}$ \\
\hline Observations & 11,243 & 11,243 & 11,100 & 1,024 & 1,024 & 11,243 & 5,222 \\
\hline No. Municipalities & 1,024 & 1,024 & 1,011 & 1,024 & 1,024 & 1,024 & 475 \\
\hline$R^{2}$ (within) & 0.014 & 0.016 & 0.072 & 0.085 & 0.089 & na & na \\
\hline Transfer formula controls & No & Yes & Yes & No & Yes & Yes & Yes \\
\hline $\begin{array}{l}\text { Time-invariant controls } \times \\
\text { Year dummies }\end{array}$ & No & No & Yes & na & na & No & No \\
\hline
\end{tabular}

Notes: Robust standard errors in parentheses (clustered at the municipality level in models 1-3 and 6-7 and clustered at the department level in models 4-5). All linear models include a full set of municipality and year dummies. ${ }^{* * *},{ }^{* *}$, and $*$ indicate statistical significance at the $1 \%, 5 \%$, and $10 \%$ level, respectively. 
Table 3

The Effect of Fiscal Transfers on Political Violence, Full Model

\begin{tabular}{|c|c|c|c|c|c|c|c|c|}
\hline \multirow[t]{2}{*}{ Dependent variable } & \multicolumn{8}{|c|}{ Homicides of Public Officials, Politicians and Candidates } \\
\hline & $(1)$ & $(2)$ & $(3)$ & $(4)$ & $(5)$ & $(6)$ & $(7)$ & $(8)$ \\
\hline Log $(\text { per-capita CG transfer })_{t-1}$ & $\begin{array}{c}0.063^{* * *} \\
(0.014)\end{array}$ & $\begin{array}{c}0.071^{* * *} \\
(0.018)\end{array}$ & $\begin{array}{c}0.059^{* * *} \\
(0.014)\end{array}$ & $\begin{array}{c}0.064^{* * *} \\
(0.017)\end{array}$ & $\begin{array}{c}0.061^{* * *} \\
(0.014)\end{array}$ & $\begin{array}{c}0.062^{* * *} \\
(0.018)\end{array}$ & $\begin{array}{c}0.093^{* * *} \\
(0.020)\end{array}$ & $\begin{array}{c}0.080^{* * *} \\
(0.021)\end{array}$ \\
\hline $\begin{array}{l}\text { Log }(\text { per-capita CG transfer })_{t-1} \\
\times \text { Police Stations } 1995\end{array}$ & $\begin{array}{c}-0.009^{* * *} \\
(0.002)\end{array}$ & $\begin{array}{c}-0.016^{* *} \\
(0.006)\end{array}$ & & & & & & \\
\hline $\begin{array}{l}\text { Log }(\text { per-capita CG transfer })_{t-1} \\
\times \text { Courts } 1995\end{array}$ & & & $\begin{array}{c}-0.004^{* * *} \\
(0.001)\end{array}$ & $\begin{array}{c}-0.008^{* * *} \\
(0.003)\end{array}$ & & & & \\
\hline $\begin{array}{l}\text { Log }(\text { per-capita CG transfer })_{t-1} \\
\times \text { Notaries }_{1995}\end{array}$ & & & & & $\begin{array}{c}-0.018^{* * *} \\
(0.005)\end{array}$ & $\begin{array}{c}-0.032^{* *} \\
(0.013)\end{array}$ & & \\
\hline $\begin{array}{l}\text { Log }(\text { per-capita CG transfer })_{t-1} \\
\quad \times \text { Tax Capacity } 1985-1987\end{array}$ & & & & & & & $\begin{array}{c}-0.197^{* * *} \\
(0.069)\end{array}$ & $\begin{array}{c}-0.147^{* *} \\
(0.066)\end{array}$ \\
\hline Observations & 10,878 & 10,757 & 10,944 & 10,812 & 10,867 & 10,735 & 10,963 & 10,831 \\
\hline No. Municipalities & 989 & 978 & 995 & 983 & 988 & 976 & 997 & 985 \\
\hline$R^{2}$ (within) & 0.037 & 0.091 & 0.040 & 0.095 & 0.037 & 0.091 & 0.020 & 0.072 \\
\hline Transfer formula controls & No & Yes & No & Yes & No & Yes & No & Yes \\
\hline $\begin{array}{l}\text { Time-invariant controls } \times \text { Year } \\
\text { dummies }\end{array}$ & No & Yes & No & Yes & No & Yes & No & Yes \\
\hline
\end{tabular}

Notes: Robust standard errors in parentheses (clustered at the municipality level). All models include a full set of municipality and year dummies. $*^{* *},{ }^{* *}$, and $*^{*}$ indicate statistical significance at the $1 \%, 5 \%$, and $10 \%$ level, respectively. 
Table 3A

Long-Difference Estimates, Full Model

\begin{tabular}{|c|c|c|c|c|c|c|c|c|}
\hline \multirow[t]{2}{*}{ Dependent variable } & \multicolumn{8}{|c|}{ Homicides of Public Officials, Politicians and Candidates } \\
\hline & $(1)$ & $(2)$ & $(3)$ & $(4)$ & $(5)$ & $(6)$ & $(7)$ & $(8)$ \\
\hline Log (per-capita CG transfer $)_{t-1}$ & $\begin{array}{c}0.074^{* * *} \\
(0.028)\end{array}$ & $\begin{array}{c}0.062^{* *} \\
(0.027)\end{array}$ & $\begin{array}{c}0.067^{* *} \\
(0.028)\end{array}$ & $\begin{array}{c}0.056^{* *} \\
(0.027)\end{array}$ & $\begin{array}{l}0.066^{* *} \\
(0.029)\end{array}$ & $\begin{array}{l}0.049^{*} \\
(0.028)\end{array}$ & $\begin{array}{c}0.107^{* * *} \\
(0.030)\end{array}$ & $\begin{array}{c}0.091^{* * *} \\
(0.030)\end{array}$ \\
\hline $\begin{array}{l}\text { Log }(\text { per-capita CG transfer })_{t-1} \\
\times \text { Police Stations } 1995\end{array}$ & $\begin{array}{l}-0.017^{*} \\
(0.009)\end{array}$ & $\begin{array}{l}-0.017^{*} \\
(0.009)\end{array}$ & & & & & & \\
\hline $\begin{array}{l}\text { Log }(\text { per-capita CG transfer })_{t-1} \\
\times \text { Courts } 1995\end{array}$ & & & $\begin{array}{c}-0.008^{* *} \\
(0.004)\end{array}$ & $\begin{array}{c}-0.008^{* *} \\
(0.004)\end{array}$ & & & & \\
\hline $\begin{array}{l}\text { Log }(\text { per-capita CG transfer })_{t-1} \\
\times \text { Notaries } 1995\end{array}$ & & & & & $\begin{array}{l}-0.036^{*} \\
(0.020)\end{array}$ & $\begin{array}{l}-0.036^{*} \\
(0.020)\end{array}$ & & \\
\hline $\begin{array}{l}\text { Log (per-capita CG transfer) }{ }_{t-1} \\
\quad \times \text { Tax Capacity } 1985-1987\end{array}$ & & & & & & & $\begin{array}{c}-0.196^{* *} \\
(0.090)\end{array}$ & $\begin{array}{l}-0.172^{*} \\
(0.092)\end{array}$ \\
\hline Observations & 989 & 989 & 995 & 995 & 988 & 988 & 997 & 997 \\
\hline No. Municipalities & 989 & 989 & 995 & 995 & 988 & 988 & 997 & 997 \\
\hline$R^{2}$ (within) & 0.156 & 0.158 & 0.175 & 0.176 & 0.153 & 0.157 & 0.097 & 0.1 \\
\hline Transfer formula controls & No & Yes & No & Yes & No & Yes & No & Yes \\
\hline
\end{tabular}

Notes: Robust standard errors in parentheses (clustered at the departmental level). All models include a full set of departmental dummies. $* * * * *$, and $*$ indicate statistical significance at the $1 \%, 5 \%$, and $10 \%$ level, respectively. 
Table 4

Sensitivity Analysis with Armed Group Presence

\begin{tabular}{|c|c|c|c|c|c|c|c|c|}
\hline \multirow[t]{2}{*}{ Dependent variable } & \multicolumn{8}{|c|}{ Homicides of Public Officials, Politicians and Candidates } \\
\hline & $(1)$ & $(2)$ & $(3)$ & $(4)$ & $(5)$ & $(6)$ & $(7)$ & $(8)$ \\
\hline Log (per-capita CG transfer) ${ }_{t-1}$ & $\begin{array}{c}0.013 \\
(0.011)\end{array}$ & $\begin{array}{c}0.060^{* * *} \\
(0.021)\end{array}$ & $\begin{array}{l}0.103^{* *} \\
(0.044)\end{array}$ & $\begin{array}{c}0.113^{* *} \\
(0.046)\end{array}$ & $\begin{array}{c}0.016 \\
(0.011)\end{array}$ & $\begin{array}{c}0.081^{* * *} \\
(0.022)\end{array}$ & $\begin{array}{c}0.132^{* * *} \\
(0.044)\end{array}$ & $\begin{array}{c}0.142^{* * *} \\
(0.047)\end{array}$ \\
\hline $\begin{array}{l}\text { Log (per-capita CG transfer) })_{t-1} \\
\times \text { Police Stations } 1995\end{array}$ & & & & & $\begin{array}{c}-0.020^{* * *} \\
(0.004)\end{array}$ & $\begin{array}{c}-0.016^{* * *} \\
(0.006)\end{array}$ & $\begin{array}{c}-0.017^{* * *} \\
(0.006)\end{array}$ & $\begin{array}{c}-0.019 * * * \\
(0.006)\end{array}$ \\
\hline Armed Group Presence: & $\begin{array}{c}\text { No } \\
\text { Presence }\end{array}$ & Guerrilla & $\begin{array}{l}\text { Paramili- } \\
\quad \text { taries }\end{array}$ & Both & $\begin{array}{l}\text { No } \\
\text { Presence }\end{array}$ & Guerrilla & $\begin{array}{l}\text { Paramili- } \\
\quad \text { taries }\end{array}$ & Both \\
\hline Observations & 2,344 & 8,481 & 4,035 & 3,760 & 2,244 & 8,238 & 3,938 & 3,663 \\
\hline No. Municipalities & 214 & 772 & 367 & 342 & 204 & 749 & 358 & 333 \\
\hline$R^{2}$ (within) & 0.186 & 0.079 & 0.106 & 0.110 & 0.239 & 0.099 & 0.130 & 0.138 \\
\hline
\end{tabular}

Note: All Models include Transfer formula controls + Time-invariant controls $\times$ Year dummies

Notes: Robust standard errors in parentheses (clustered at the municipality level). All models include a full set of municipality and year dummies. ${ }^{* *}, * *$, and $*$ indicate statistical significance at the $1 \%, 5 \%$, and $10 \%$ level, respectively. 
Table 4 (cont)

Sensitivity Analysis with Armed Group Presence

\begin{tabular}{|c|c|c|c|c|c|c|c|c|c|c|c|c|}
\hline \multirow[t]{2}{*}{ Dependent variable } & \multicolumn{12}{|c|}{ Homicides of Public Officials, Politicians and Candidates } \\
\hline & (9) & $(10)$ & $(11)$ & $(12)$ & $(13)$ & $(14)$ & $(15)$ & $(16)$ & $(17)$ & $(18)$ & $(19)$ & $(20)$ \\
\hline Log (per-capita CG transfer) $)_{t-1}$ & $\begin{array}{l}0.019^{*} \\
(0.011)\end{array}$ & $\begin{array}{c}0.072^{* * *} \\
(0.021)\end{array}$ & $\begin{array}{c}0.132^{* * *} \\
(0.043)\end{array}$ & $\begin{array}{c}0.142^{* * *} \\
(0.045)\end{array}$ & $\begin{array}{c}0.015 \\
(0.012)\end{array}$ & $\begin{array}{c}0.070^{* * *} \\
(0.022)\end{array}$ & $\begin{array}{l}0.128^{* * *} \\
(0.044)\end{array}$ & $\begin{array}{c}0.137^{* * *} \\
(0.046)\end{array}$ & $\begin{array}{l}0.025^{*} \\
(0.015)\end{array}$ & $\begin{array}{c}0.089^{* * *} \\
(0.025)\end{array}$ & $\begin{array}{r}0.187^{* * *} \\
(0.050)\end{array}$ & $\begin{array}{c}0.209^{* * *} \\
(0.053)\end{array}$ \\
\hline $\begin{array}{l}\text { Log (per-capita CG transfer) })_{t-1} \\
\times \text { Courts }_{1995}\end{array}$ & $\begin{array}{c}-0.008 * * * \\
(0.002)\end{array}$ & $\begin{array}{c}-0.008^{* * *} \\
(0.003)\end{array}$ & $\begin{array}{c}-0.008^{* * *} \\
(0.002)\end{array}$ & $\begin{array}{c}-0.009 * * * \\
(0.002)\end{array}$ & & & & & & & & \\
\hline $\begin{array}{l}\text { Log (per-capita CG transfer) })_{t-1} \\
\times \text { Notaries } 1995\end{array}$ & & & & & $\begin{array}{c}-0.030^{* * * *} \\
(0.010)\end{array}$ & $\begin{array}{c}-0.033^{* *} \\
(0.013)\end{array}$ & $\begin{array}{c}-0.037^{* * *} \\
(0.013)\end{array}$ & $\begin{array}{c}-0.040^{* * *} \\
(0.012)\end{array}$ & & & & \\
\hline $\begin{array}{l}\text { Log }(\text { per-capita CG transfer })_{t-1} \\
\quad \times \text { Tax Capacity } 1985-1987\end{array}$ & & & & & & & & & $\begin{array}{l}-0.058 \\
(0.049)\end{array}$ & $\begin{array}{c}-0.165^{* *} \\
(0.084)\end{array}$ & $\begin{array}{r}-0.350^{* *} \\
(0.165)\end{array}$ & $\begin{array}{c}-0.387^{* *} \\
(0.171)\end{array}$ \\
\hline Armed Group Presence: & $\begin{array}{l}\text { No } \\
\text { Presence }\end{array}$ & Guerrilla & $\begin{array}{l}\text { Parami- } \\
\text { litaries }\end{array}$ & Both & $\begin{array}{c}\text { No } \\
\text { Presence }\end{array}$ & Guerrilla & $\begin{array}{l}\text { Parami- } \\
\text { litaries }\end{array}$ & Both & $\begin{array}{l}\text { No } \\
\text { Presence }\end{array}$ & Guerrilla & $\begin{array}{l}\text { Parami- } \\
\text { litaries }\end{array}$ & Both \\
\hline Observations & 2,255 & 8,282 & 3,938 & 3,663 & 2,244 & 8,216 & 3,905 & 3,630 & 2,284 & 8,272 & 3,916 & 3,641 \\
\hline No. Municipalities & 205 & 753 & 358 & 333 & 204 & 747 & 355 & 330 & 208 & 752 & 356 & 331 \\
\hline$R^{2}$ (within) & 0.23 & 0.103 & 0.135 & 0.143 & 0.224 & 0.100 & 0.131 & 0.139 & 0.194 & 0.080 & 0.110 & 0.115 \\
\hline
\end{tabular}

Note: All Models include Transfer formula controls + Time-invariant controls $\times$ Year dummies

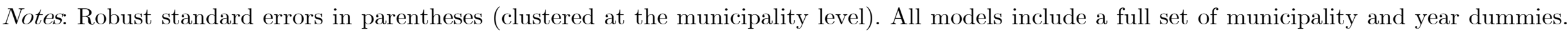
$* * *, * *$, and $*$ indicate statistical significance at the $1 \%, 5 \%$, and $10 \%$ level, respectively. 
Table 5

The Effect of Fiscal Transfer on Other Conflict Outcomes, Restricted Model

\begin{tabular}{|c|c|c|c|c|c|c|}
\hline \multirow{2}{*}{$\begin{array}{l}\text { Conflict Outcomes: } \\
\text { Dependent } \\
\text { variable: }\end{array}$} & \multicolumn{2}{|c|}{ Terrorists Attacks } & \multicolumn{2}{|c|}{$\begin{array}{c}\text { Military } \\
\text { Confrontation }\end{array}$} & \multicolumn{2}{|c|}{$\begin{array}{l}\text { Violence against } \\
\text { Civilians }\end{array}$} \\
\hline & $\begin{array}{c}\text { Explosives } \\
\text { (1) }\end{array}$ & $\overline{\text { Infrastructure }}$ & $\begin{array}{c}\text { Guerrilla } \\
\text { Combats } \\
(3)\end{array}$ & $\begin{array}{c}\text { Military } \\
\text { Casualties } \\
(4)\end{array}$ & $\begin{array}{c}\text { Homicides } \\
\text { (5) }\end{array}$ & $\begin{array}{c}\text { Displaced } \\
\text { Households } \\
(6)\end{array}$ \\
\hline Log (per-capita CG transfer) ${ }_{t-1}$ & $\begin{array}{c}0.024 \\
(0.045)\end{array}$ & $\begin{array}{c}0.019 \\
(0.030)\end{array}$ & $\begin{array}{c}0.052 \\
(0.045)\end{array}$ & $\begin{array}{l}-0.019 \\
(0.040)\end{array}$ & $\begin{array}{c}-0.283^{* *} \\
(0.115)\end{array}$ & $\begin{array}{c}-14.228^{*} \\
(8.434)\end{array}$ \\
\hline Observations & 11,100 & 11,100 & 11,100 & 11,100 & 11,100 & 4,752 \\
\hline No. Municipalities & 1,011 & 1,011 & 1,011 & 1,011 & 1,011 & 792 \\
\hline$R^{2}$ (within) & 0.121 & 0.452 & 0.115 & 0.080 & 0.203 & 0.157 \\
\hline
\end{tabular}

Note: All Models include Transfer formula controls + Time-invariant controls $\times$ Year dummies

Notes: Robust standard errors in parentheses (clustered at the municipality level). All models include a full set of municipality and year dummies. ${ }^{* * *},{ }^{* *}$, and ${ }^{*}$ indicate statistical significance at the $1 \%, 5 \%$, and $10 \%$ level, respectively. 